\title{
Deep primary production in coastal pelagic systems: importance for ecosystem functioning
}

\author{
Maren Moltke Lyngsgaard ${ }^{1,2, *}$, Katherine Richardson ${ }^{1}$, Stiig Markager ${ }^{2}$, \\ Morten Holtegaard Nielsen ${ }^{3}$, Michael Olesen ${ }^{4}{ }_{\text {Jesper Philip Aagaard Christensen }}{ }^{2}$ \\ ${ }^{1}$ Center for Macroecology, Evolution and Climate, Danish Natural History Museum, University of Copenhagen, \\ 2200 Copenhagen, Denmark \\ ${ }^{2}$ Department of Bioscience, Marine Diversity and Experimental Ecology, Aarhus University, 4000 Roskilde, Denmark \\ ${ }^{3}$ Arctic Technology Centre, Department of Civil Engineering, Technical University of Denmark, Kemitorvet, Building 204, \\ 2800 Kgs. Lyngby, Denmark \\ ${ }^{4}$ Department of Marine Biology, Copenhagen University, 3000 Helsingør, Denmark
}

\begin{abstract}
Monitoring data (1999 to 2012) and data from a 2 wk field study at a seasonally stratified station in the Aarhus Bight near the Danish coast were used to demonstrate that the vertical distribution of photosynthesis influences both water column oxygen conditions and the fate of the organic material produced. The primary production (PP) occurring below the surface layer, i.e. in the pycnocline-bottom layer (PBL), is shown to contribute significantly to total PP. Oxygen concentrations in the PBL are shown to correlate significantly with the deep primary production (DPP) as well as with salinity, phosphate loading, wind and transparency in the surface layer. The phytoplankton communities detected in the surface layer and PBL during the field study were very different. Large cells, especially Ceratium spp., dominated in the PBL, while small diatoms, mainly Proboscis alata, dominated in surface waters. On the basis of chlorophyll-normalised photosynthetic parameters and variable fluorescence, it is shown that the 2 populations were physiologically distinct. The population in the PBL was photosynthetically active and adapted/ acclimated to lower light than the population in the surface layer. Sinking rates (based on sediment trap collections) of carbon and nitrogen were highest in the PBL. Lyngsgaard et al. (2014; Limnol Oceanogr 59:1679-1690) have demonstrated that the vertical distribution of PP in this region is influenced by anthropogenic nutrient loading. Thus, the present study indicates that eutrophication effects may include changes in the structure of planktonic food webs and element cycling in the water column, both brought about through an altered vertical distribution of PP.
\end{abstract}

KEY WORDS: Primary production - Light attenuation - Vertical distribution · Phytoplankton species distribution $\cdot$ Sedimentation $\cdot$ Oxygen concentration

\section{INTRODUCTION}

Deep chlorophyll maxima (DCM) have been demonstrated to be a consistent feature in permanently stratified regions, i.e. tropical and sub-tropical seas (see e.g. Sedwick et al. 2005, Benitez-Nelson et al. 2007) and a seasonal feature in many temporal and polar regions (Estrada et al. 1993, Holm-Hansen \& Hewes 2004). In regions with very high insolation rates, phytoplankton may experience photoinhibition and, therefore, avoid immediate surface waters (see e.g. Platt et al. 1980, Falkowski 1984), but in general, the DCM is believed to occur where there is an optimal combination of light and nutrients for phytoplankton growth and production (Klausmeier \& Litchman 2001, Beckmann \& Hense 2007, Ross \& Sharples 2007). In some cases, especially in permanently stratified regions such as the tropics, the DCM 
does not always coincide with a biomass maximum (Marañón et al. 2000, Richardson et al. 2014) but, rather, is believed to reflect increases in chl a per cell in low light-adapted cells (Claustre \& Marty 1995, Marañón et al. 2000). However, in seasonally stratified regions, DCMs usually coincide with a biomass maximum (Richardson \& Christoffersen 1991, Richardson et al. 2000). Initially, it was assumed that DCMs represented accumulations of sinking cells (Riley et al. 1949). However, in recent decades, it has been demonstrated that DCMs are usually comprised of photosynthetically active phytoplankton originating from sinking cells, advective processes and in situ growth and that they can contribute substantially to overall water column productivity with e.g. up to $75 \%$ on a daily basis in the Dogger Bank area (Richardson et al. 1998) and up to $30 \%$ on an annual basis in the Southern Kattegat (e.g. Richardson \& Christoffersen, 1991, Lyngsgaard et al. 2014). Significant subsurface primary production (PP) has been shown to be a feature of stratified areas in various parts of the world oceans (see e.g. Holligan et al. 1984, Richardson et al. 2000, 2005, Kononen et al. 2003, Veldhuis \& Kraay 2004, Weston et al. 2005, Hickman et al. 2012, Martin et al. 2013).

Phytoplankton populations associated with DCMs often exhibit a different physiological response to light than their counterparts in surface waters, suggesting that they represent communities distinct from those at the surface (see e.g. Richardson et al. 1983, Moore et al. 2006). In principle, these physiological differences can result from phenotypic responses, i.e. similar species in both surface waters and DCM but with altered composition of the photosynthetic units, chlorophyll content and other physiological responses, and/or genotypic responses, i.e. selection for different species in the 2 layers. Indeed, a number of studies have demonstrated that phytoplankton species composition can vary significantly between surface waters and the DCM (e.g. Furuya \& Marumo 1983, Richardson et al. 2005, Hickman et al. 2009) as well as vertically within the DCM and surface waters themselves (Mouritsen \& Richardson 2003) due to in situ growth, interspecific interactions and/or selective sinking linked to the availability of nutrients (Dortch et al. 2001). It has also been suggested that photosynthesis occurring in association with DCMs can ameliorate hypoxia in some stratified water systems (Dortch et al. 1994, Lehrter et al. 2009, Murrell et al. 2009, Strom et al. 2010). Despite these observations, most models describing marine ecosystems do not accommodate for potential heterogeneity in the vertical distribution of PP. Specifically, such models tend to ei- ther ignore the production of organic material and oxygen below the pycnocline (Bendtsen \& Hansen 2013) or assume that PP is linearly related to light (i.e. without light saturation) and apply only 1 factor for light affinity for all phytoplankton cells (Neumann 2000, Maar \& Hansen 2011).

$\mathrm{PP}$ is known to persistently occur below the surface water layer during summer in Aarhus Bight, a region located centrally in the Baltic Sea transition zone (BSTZ) and where phytoplankton growth and production have been shown to be nutrient limited in the surface mixed layer during the summer months (Jørgensen 1996). On the other hand, the layer below the surface waters has been shown to exhibit relatively high inorganic nutrient concentrations throughout the summer largely as a result of nutrient release from sediments (Jørgensen 1996). The production and grazing occurring in the subsurface layer were demonstrated to lead to a greater vertical flux of organic material to the sediment floor from this layer as compared to the surface layer, and several blooms of flagellated phytoplankton forms were observed to occur in the subsurface layer. The oxygen conditions were, however, not analysed in relation to the subsurface PP (Jørgensen 1996).

Light and nutrients vary throughout the water column and there is no a priori reason to assume that changes in nutrient loading will influence PP in different layers of the water column equally. Lyngsgaard et al. (2014) demonstrated that nitrogen loading from land runoff correlates positively with PP in the surface layer and negatively with PP below the surface layer.

Traditionally, eutrophication effects have mostly been considered in terms of total water column production (e.g. Nixon 1995, Smith 2003, Howarth et al. 2011). The recognition that nutrient loading can influence the vertical distribution of PP calls for a better understanding of production processes and the fate of organic material produced in the different vertical strata of the water column. The purpose of this study was, therefore, to explicitly describe characteristics of phytoplankton populations in the surface layer and below the surface, i.e. in a layer including both the pycnocline and the bottom waters (hereafter referred so as the pycnocline-bottom layer, PBL), in an effort to compare their potential contributions to oxygen conditions in the water column and the functioning of the planktonic ecosystem. We hypothesised that (1) the vertical distribution of PP affects the bottom water oxygen conditions in the BSTZ and (2) that differences in taxonomic composition between communities in the surface layer and in the PBL may 
lead to differences in sinking rates for the organic material produced by photosynthesis in the different depth strata. These hypotheses were tested using monitoring data collected between 1999 and 2012 and field studies conducted in 2010 in Aarhus Bight (Southern Kattegat). The Kattegat and Belt Seas form the BSTZ and are consistently stratified during summer months where hypoxia is a frequent and reoccurring condition in this area (Conley et al. 2002).

\section{MATERIALS AND METHODS}

This study is based on data retrieved from the Danish National Aquatic Monitoring and Assessment Program (MAPS; Conley et al. 2002) and from a field study carried out in July 2010 on the Aarhus University research ship 'Tyra'. The data from MAPS is publically available in the MADS, ODA and ODAM databases (see following link for the MADS database: www2.dmu.dk/1_viden/2_Miljoe-tilstand/3_vand/4_ mads_ny/default_en.asp), and the data analysed in

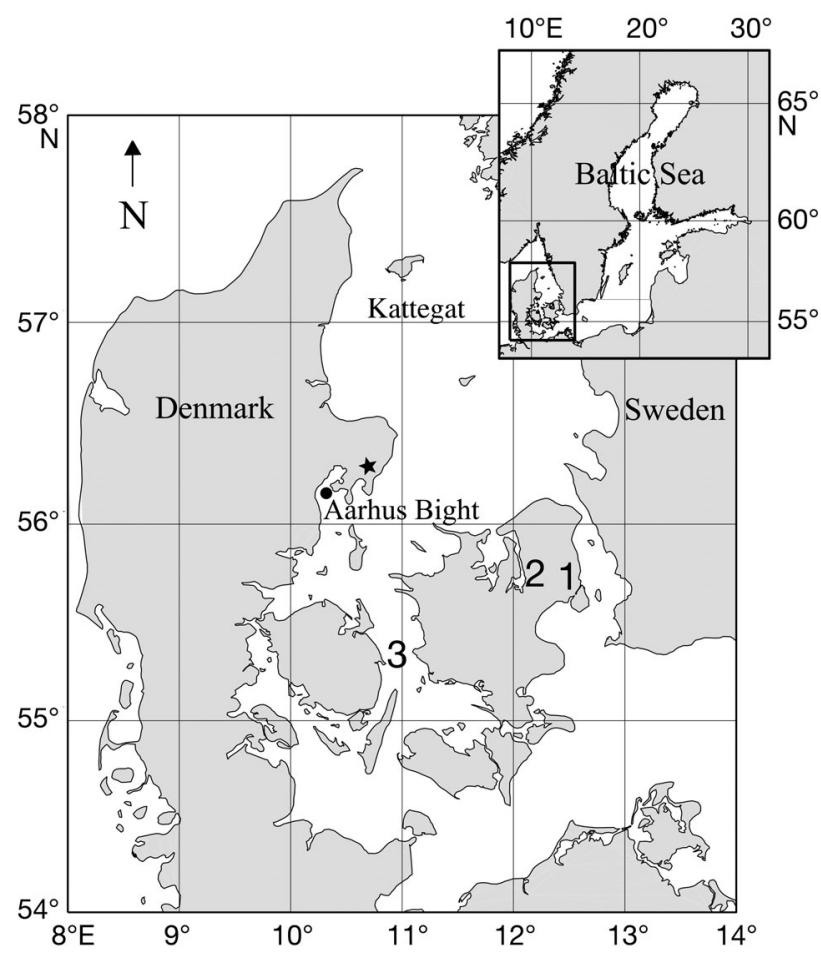

Fig. 1. Baltic Sea transition zone (BSTZ) consisting of the Kattegat and the Belt Sea (Danish Straits) showing (•) the sampling station in Aarhus Bight, $(\star)$ the weather station (wind measurements) and the surface photosynthetically active radiation (SPAR) measuring stations: (1) Hans Christian Ørsted Institute and University of Copenhagen, (2) Risø (Danish Technical University), and (3) the Great Belt bridge. An orientation map of the Baltic Sea area is included in the top right corner this study were recorded at $56^{\circ} 09^{\prime} 10^{\prime \prime} \mathrm{N}, 10^{\circ} 19^{\prime} 20^{\prime \prime} \mathrm{E}$ (Fig. 1). The analyses carried out during the field study were conducted following the same procedures as used in MAPS for all measurements that are also reported in that database. All procedures in the monitoring programme have been described in common technical guidelines (Kaas \& Markager 1998), and quality control was ensured by frequent inter-comparisons of data collected by different contributors.

The study approach was to complement a robust dataset of continuous measurements (chlorophyll, fluorescence, photosynthesis versus irradiance curves $[P$ vs. $E]$, photosynthetically active radiation [PAR], oxygen, temperature, salinity and depth) with a detailed field study where sedimentation and phytoplankton community structure and physiology could be compared between the surface and subsurface layers of the water column. General patterns identified in the monitoring dataset were used to ensure that the field study took place during a period where the probability of sampling a DCM was high. The monitoring data were first divided into 2 layers (surface and below surface [PBL]) using physical parameters. Photosynthetic parameters had been measured in both layers and $P$ vs. $E$ curves, together with PAR and chlorophyll derived from fluorescence profiles, were used to calculate the PP in each layer. Oxygen concentrations and related parameters from the monitoring data were analysed with a multiple linear regression method to find the parameters with the largest explanatory power. PP in the PBL was correlated to these oxygen concentrations. The field study examined potential differences in the fate of PP in the 2 strata of the water column. The different methods and procedures used to analyse the time series and the field measurements are described in the following sections.

\section{Study area}

The BSTZ can be characterised as a large frontal system where the low-saline surface waters from the Baltic Sea are mixed with the more saline waters coming from the Skagerrak. Aarhus Bight (Fig. 1) is a semi-enclosed area, i.e. open to exchange in one direction only. It is south of the Kattegat and so the deep water masses of the Kattegat are predominantly found here and changes in the water masses in the upper layer can be substantial in connection with outflow from the Baltic (Jørgensen 1996, Nielsen 2005). Aarhus Bight, therefore, represents a suitable location for the investigation of plankton dynamics in 
looking from a vertical perspective in the BSTZ. In Aarhus Bight, the average surface (0 to $5 \mathrm{~m}$ ) salinities range from about 18.8 to 24.4 during different months of the year, and average bottom layer $(>12 \mathrm{~m})$ salinities range from about 25.7 to 29 (values from 1999 to 2012 extracted from the MADS). The average temperatures vary between 2.9 and $17.9^{\circ} \mathrm{C}$ at the surface and between 3.6 and $14.2^{\circ} \mathrm{C}$ in the bottom water.

\section{CTD profiles}

Profiles of salinity, temperature, chl a fluorescence, PAR and oxygen concentration in Aarhus Bight were extracted from the MADS database for the years 1999 to 2012. Between 1 and 10 (average $=4$ ) CTD profiles were made in each month. During the field study, a Seabird 911 was used. Oxygen concentration and fluorescence were profiled with an SBE 43 with a Clark electrode and a Wetlab fluorometer (model FLNTURT), respectively. The profiling oxygen sensor was calibrated with measurements made on discrete water samples using a dissolved oxygen analyser (SiS DO Analyser, ser. no. 8045). The fluorometer was calibrated with spectrophotometric determination of chl a from discrete depths (see 'Chl a concentration' below). Both the ship and the instruments used have previously contributed to the MAPS programme.

\section{Division of the water column into 2 layers}

Salinity and temperature profiles were used to calculate density ( $\rho$ ) (UNESCO 1981). A total of 613 density profiles made between 1999 and 2012 were used to calculate the starting depth of the pycnocline, defined with a density criterion value of $1 \mathrm{~kg} \mathrm{~m}^{-3}$ per $\mathrm{m}\left(=1 \mathrm{~kg} \mathrm{~m}^{-4}\right)$. Thus, a pycnocline was defined as being present when this density criterion was met at a depth of $\geq 3$ from the surface and $\geq 1 \mathrm{~m}$ from above the bottom. This depth interval was chosen in order to exclude short-lived stratification that occasionally develops in the immediate surface waters, i.e. when insolation is high. Waters close to the bottom were excluded as there can be CTD noise in very nearbottom waters. The average monthly frequency of the presence of a pycnocline was calculated as the percentage of sampling days when a pycnocline was present.

For each day with a distinct pycnocline, all depths in the water column were assigned to 1 of 2 layers, i.e. either below the surface layer (i.e. in the PBL) or in the surface layer. This made it possible to consider the PP occurring in each layer: surface PP (SPP) and deep PP (DPP), i.e. the PP occurring in the PBL. Note that we do not distinguish whether DPP is occurring in the pycnocline region or below in the bottom layer but simply when PP is occurring below the surface layer. This was because we assume that all oxygen produced by photosynthesis in the surface layer can potentially exchange with atmospheric oxygen, while that produced in the pycnocline region or below cannot. When the density criterion of $\Delta \rho / \Delta z$ (i.e. changes in density per meter depth) $>1 \mathrm{~kg} \mathrm{~m}^{-4}$ was absent from the water column, all PP was considered as being SPP.

The density criterion chosen here was not intended to identify the depth of the surface mixed layer, as is common in many studies but used rather to delineate the pycnocline-bottom waters from the remaining water column. The idea was to approach the water column with the 'eyes' of a phytoplankton and divide the water column so that the different environments with respect to oxygen, light and nutrients were separated, and since the surface mixed layer represents a more homogenous environment due to vertical mixing, we found it useful to separate this layer from the remaining water column. The BSTZ shows relatively large density differences between surface and bottom waters and the density criterion is, therefore, relatively high compared to those previously used in the literature to separate water layers in marine systems (Kara et al. 2000, de Boyer Montégut et al. 2004). A total of 256 visual inspections of density profiles were made to examine how well the density criterion matched with the depth determined visually as being the shallowest region with a markedly visible density gradient. These indicated a good match in approximately $90 \%$ of the cases. In the remaining cases, the density criterion overestimated the depth of the PBL, i.e. placed the starting depth approximately 1 to $2 \mathrm{~m}$ deeper (i.e. within the pycnocline) than the visual examination suggested. Thus, our estimate of the thickness of the PBL can be considered as conservative.

\section{Light}

PAR was measured with a spherical Licor UW sensor mounted on the CTD rosette during both the field study and the survey programme sampling. Surface PAR (SPAR) was measured at the top of the ship at the same time as the CTD casts and the data stored included the fraction of SPAR in the water column. 
Values for the diffuse light attenuation coefficient $\left(K_{\mathrm{d}}, \mathrm{m}^{-1}\right)$ were estimated for each profile. PP from both the field study and MAPS was calculated with a second set of SPAR data because of high variation between different ship-based measurements of SPAR. This dataset was comprised of values from different land-based localities in Denmark within approximately 30 to $150 \mathrm{~km}$ of Aarhus Bight (see Fig. 1 for placement of locations) that were measured throughout the study period and averaged for every $30 \mathrm{~min}$.

\section{Flow velocities}

Observations of flow velocities were made using a $600 \mathrm{kHz}$ WorkHorse Monitor ADCP (Acoustic Doppler Current Profiler) from Teledyne RDI, which was mounted looking downward over the side of the vessel. The depth cell size of the instrument was either 25 or $50 \mathrm{~cm}$, whereas other primary settings, such as the blanking depth $(100 \mathrm{~cm})$, the transducer depth $(50 \mathrm{~cm})$ and the ambiguity velocity $\left(3.30 \mathrm{~m} \mathrm{~s}^{-1}\right)$ were kept constant. The data were collected using single pings, and the instrument was set to ping as fast as possible resulting in about 1 record per second. Although anchored, the vessel used for the field surveys was in constant motion due to wind, waves and currents. To account for these movements, the velocity of the vessel (found using the bottom track of the instrument) was subtracted. The flow speed of water movement was calculated as a vertical average of the velocity observations made in the 3 depth intervals; 3 to $5 \mathrm{~m}, 8$ to $10 \mathrm{~m}$ and 13 to $15 \mathrm{~m}$.

\section{Chl a concentration}

Determination of chl a concentration in water samples and sediment trap material was carried out by filtering ( 0.2 bar generated by a vacuum pump) through Whatman GF/F or GF 75 Advantec filters and extracting the chl $a$ in ethanol (96\%) for 6 to $20 \mathrm{~h}$. The extract was centrifuged and absorption at $665 \mathrm{~nm}$ was determined spectrophotometrically before and after acidification $(1 \mathrm{~N} \mathrm{HCl})$, according to the method described by Strickland \& Parsons (1972) and modified by Dansk Standard (1986). Samples from the field study were analysed fluorometrically (TD-700 Turner fluorometer) according to Lorenzen (1967) when the concentration was too low for spectrophotometric analysis (sediment traps and size-fractionated samples).
In the field study, chl a was fractioned by size using a vacuum pump (0.2 bar) and glass fibre filters with 3 different pore sizes: $56 \mu \mathrm{m}$ (NY56.047), $10 \mu \mathrm{m}$ (NY10.047) and $0.7 \mu \mathrm{m}$ (Whatman GF/F or G5 75 Advantec). Fresh sample water was used on each filter size so that no water sample was filtered more than once. Thus, we obtained values for chl a originating in plankton retained on filters of 3 different pore sizes. The concentration of chl a from phytoplankton larger than $0.7 \mu \mathrm{m}$ but smaller than $10 \mu \mathrm{m}$ was obtained by subtracting the concentration retained on the $10 \mu \mathrm{m}$ filter from the concentration found on the $0.7 \mu \mathrm{m}$ filter. This procedure was repeated to obtain an estimate for the 10 to $56 \mu \mathrm{m}$ size fraction.

A continuous chl a profile (depth resolution $0.2 \mathrm{~m}$ ) was constructed from the GF 75 measurements of chl $a$ and profile data for fluorescence. Sampling depths were $1,5,10$ and $15 \mathrm{~m}$ for the survey programme and similarly 3 to 4 depths for the field study $(1,14 \mathrm{~m}$ and 1 or 2 samples in between where 1 sample was taken in the PBL chlorophyll peak, if present). Fluorescence per unit chl a changed systematically with depth. Therefore, a fluorescence factor $\left(F_{\text {chl }}=F /[\right.$ chl $\left.]\right)$ was calculated for each depth with a chl a concentration recorded in the discrete samples. Values for $F_{\text {chl }}$ between sampling depths were assigned by linear interpolation and used to estimate a continuous chl a profile, i.e. $\operatorname{chl}(z)=F(z) / F_{\text {chl }}(z)$.

\section{Primary production}

The MADS database contains data on photosynthetic carbon uptake in Aarhus Bight on 225 d during 1999 to 2012 (excluding 2004 and 2009). Each $P$ vs. $E$ curve was based on 7 data points (incubation bottles) and $P$ vs. $E$ curves were established for 2 different depths. Together with CTD and estimated chl a profiles, these were used to calculate water column PP for each of the sampling dates as described below. The frequency of $P$ vs. $E$ parameter measurements in the database ranged from 1 to $4 \mathrm{mo}^{-1}$.

Measurements of PP were carried out following a modified version (Markager 1998) of the carbon-14 technique presented by Steemann Nielsen (1952) both in MAPS and in the field study. Samples were taken from 2 depths, i.e. the surface layer and deeper in the water column. The surface layer sample in the MADS data was taken from an integrated surface water sample (from 0 to $10 \mathrm{~m}$, or the depth of the pycnocline) collected either with a hose submerged to $10 \mathrm{~m}$ or by combining and mixing bottle samples collected at selected depths in the surface layer. The 
surface sample in the field study was taken from $1 \mathrm{~m}$. For both the MADS data and the field study, the deeper water sample was taken at the depth of the sub-surface chlorophyll maximum located above the $1 \%$ light level. When a subsurface chlorophyll maximum was not present (only in the MADS data), the second depth was chosen to be just below the pycnocline (located by visual inspection of the density profiles). $P$ vs. $E$ curves were calculated from ${ }^{14} \mathrm{C}$ incubations with artificial light (Osram HQI-T or high pressure halogen lamps) where the samples were incubated at 7 different light intensities for $2 \mathrm{~h}$ using the equation in Webb et al. (1974) according to Markager et al. (1999). The light intensity was adjusted to mimic surface values by moving the position of the lamp. Grids of metal were placed between the samples to achieve light attenuation (each grid attenuated $35 \%$ of incident light).

To estimate water column PP, the parameters derived from the $P$ vs. $E$ curves (initial slope of photosynthesis versus irradiance curve $[\alpha]$, light-saturated maximum photosynthetic rate $\left[P_{\max }\right]$ and intercept [c]) were normalised to chl a concentrations (measured in the same sample used for measurement of carbon uptake) and extrapolated over the water column. The parameters from the surface sample were assumed to be valid and constant from the surface to the bottom of the surface layer. From there, the parameters were interpolated linearly down to the depth of the second sample and were assumed to be constant down to the bottom.

Volumetric estimates of PP $\left(\mathrm{mg} \mathrm{C} \mathrm{m}^{-3} \mathrm{~h}^{-1}\right)$ were calculated following Eq. (1):

$$
P_{\mathrm{vol}}=P_{\max }^{\mathrm{vol}}\left[1-\exp \left(-\alpha^{\mathrm{vol}} \frac{\mathrm{PAR}}{P_{\max }^{\mathrm{vol}}}\right)\right]+C^{\mathrm{vol}}
$$

for each depth (0.2 m resolution) at 30 min intervals from the chlorophyll-specific $P$ vs. $E$ parameters, the continuous chlorophyll profile, $K_{\mathrm{d}}$ values and SPAR. PAR is the product of surface irradiance and the PAR fraction left at a given depth, PAR fraction $=(1-$ reflection) exp $\left[-K_{d}\right.$ (depth - 0.05)]. The surface reflection was assumed to be $6 \%$. A total of $261 \mathrm{PP}$ depth profiles were calculated: 255 from MADS and 6 from the field study in July 2010. Area rates were calculated as the sum over the day for all positive values of carbon uptake.

Annual PP, based on survey data, was estimated by calculating an average monthly rate and then multiplying this by the number of days in the given month. These totals were then added to give annual PP. In the case of missing data (e.g. winter months), a long term average was calculated for the month for which data were missing. In this way, data from other years were used to replace the missing data, i.e. a missing value for November in a given year would be replaced by the average value for November for the study period as a whole.

\section{Phytoplankton}

Species identification (species greater than about $2 \mu \mathrm{m}$ ) was carried out following the method described by Utermöhl (1958). Carbon biomass $\left(\mu \mathrm{C} \mathrm{C} \mathrm{l}^{-1}\right.$ ) was calculated after Strathmann (1967), and the carbon factors used were 0.13 for thecate dinoflagellates, 0.11 for athecate dinoflagellates and 0.11 for diatoms. For diatoms, the plasma volume was calculated as: bio volume $-(0.9 \cdot$ vacuole volume). It was assumed that the plasma was $1 \mu \mathrm{m}$ thick and that the vacuole volume contributed $10 \%$ to the carbon biomass.

During the field study, determination of phytoplankton species was carried out for 2 discrete depths: surface $(1 \mathrm{~m})$ and at the depth of the deep PP sample (8 to $12.2 \mathrm{~m}$ ). The samples were preserved with acidified Lugol's solution (approx. $2 \%$ in the sample) in brown glass bottles and identified by ORBICON A/S (Aarhus). Based on this identification, we were able to characterise the phytoplankton communities in different parts of the water column.

\section{Variable fluorescence using fast repetition rate fluorometry (FRRF)}

Variable fluorescence normalised to maximal fluorescence $\left(F_{\mathrm{v}} / F_{\mathrm{m}}\right)$, which indicates the potential for electron transport in Photosystem II, was measured with a FAST ${ }^{\text {TRACKA }}$ II fluorometer (Chelsea Instruments). The FAST ${ }^{\text {TRACKA }}$ was used in its profiling mode with the dark chamber enabled and a sinking velocity of maximum $0.2 \mathrm{~m} \mathrm{~s}^{-1}$. A single turnover protocol with 12 sequences per acquisition, each of which included 100 saturation flashlets, was utilised. The sequence interval was set to $100 \mathrm{~ms} . F_{\mathrm{v}} / F_{\mathrm{m}}$ was calculated from a saturation phase fit following Kolber et al. (1988). Only measurements with a qualifying saturation phase were included in the data set. To prevent any influence of previous light history, $F_{\mathrm{v}} / F_{\mathrm{m}}$ profiles were only collected at night.

\section{Nutrients}

Values for dissolved inorganic nitrogen (DIN) and phosphorus (DIP) were extracted from the MADS 
database. Measurements of nutrients were conducted on samples from standard depths every $5 \mathrm{~m}$ through the water column, starting at $1 \mathrm{~m}$ below the surface and ending $1 \mathrm{~m}$ above the sediment. An average value for the surface waters $(1 \mathrm{~m})$ and one for the waters close to the bottom (10 to $16.6 \mathrm{~m}$ ) was used to calculate the monthly concentrations shown in Fig. 2. The depth of $1 \mathrm{~m}$ was chosen to represent a single water mass from the surface layer.

\section{Sedimentation}

In the field study, sediment traps were deployed on 5 occasions at $6,10,12$ and $14 \mathrm{~m}$ for 24 to $48 \mathrm{~h}$. The traps had duplicate cylinders, each with a diameter of $5.2 \mathrm{~cm}$. They were used without baffles and preservatives. Before re-suspension of the sedimented material, the top layer of water in the cylinders was reduced to $650 \mathrm{ml}$. Aliquots (duplicates from 1 of 2 cylinders) were also taken for microscopy, analysis of chl $a$, and particulate organic carbon (POC) and nitrogen $(\mathrm{PON})$ determinations. Correction for the background concentration of suspended matter in the ambient water was made in the calculation of sedimentation rates. One of the cylinders in the trap array was supplied with a petri dish (covering $93 \%$ of the trap bottom) containing a high viscosity solution of $8 \%$ poly-acrylic-amide (PAA). This was done to catch and preserve intact particles and aggregates entering the trap (Lundsgaard et al. 1999). After retrieval, the dishes were taken up and the particles were allowed to settle to the bottom. A few drops of formaldehyde were added to the surface for longterm preservation and the dishes were photographed. In addition, aliquots of suspended and sedimented particulate matter from the sediment traps were collected on pre-combusted $13 \mathrm{~mm}$ Whatman $\mathrm{GF} / \mathrm{F}$ filters and stored at $-18^{\circ} \mathrm{C}$. These were measured for POC and PON on a CarboElba Eager 200 CHN elemental analyser.

\section{Analysis of oxygen saturation in the PBL}

To explore the relationship between oxygen saturation in the PBL during the summer months and different environmental variables, a partial least square (PLS) regression was done. The PLS regression combined with a jackknifing analysis was used to identify and select a subset of predicting factors from a selection of potential independent variables during the time period from 1991 to 2012. As PP was only avail- able from 1999 to 2012, it was not included in the PLS regression. The independent variables used in the initial parameter selection were $\mathrm{N}$-loading ( $\mathrm{t})$, P-loading $(\mathrm{t})$, freshwater inflow $\left(\mathrm{m}^{3}\right)$, cubed wind speed $\left(\mathrm{m}^{3} \mathrm{~s}^{-3}\right)$, surface irradiance ( $\mu \mathrm{mol}$ photons $\mathrm{m}^{-2} \mathrm{~s}^{-1}$ ), salinity (average of the surface layer, no units), water temperature (average of the surface layer, ${ }^{\circ} \mathrm{C}$ ) and light attenuation coefficient, $K_{\mathrm{d}}\left(\mathrm{m}^{-1}\right)$. Surface irradiance was the same as the one used for PP (described in 'Primary production' above). The cubed wind speed was taken from the Danish Meteorological Institute (DMI) weather station located at Tirstrup (56 $16^{\circ} \mathrm{N}, 10^{\circ} 38^{\prime} \mathrm{E}$, see Fig. 1 for location). The remaining parameters were extracted from the MAPS databases. Data on freshwater inflow, $\mathrm{N}$ - and P-loading were based on a 3D MIKE SHE groundwater resource model validated on measured total nitrogen concentrations in Danish streams. For model details, see Windolf et al. (2011a). The hydrological area chosen for this study covered the inner Aarhus Bight (area 44, see Windolf et al. 2011b for area description).

As there may be a lag period between a change in an environmental variable and a response in the biological system, different time periods were examined for a potential relationship between the environmental parameters (independent variables) and the oxygen saturation: The dependent $(Y)$ variable, in this case oxygen saturation, was constrained to a specific time period (1 July to 30 September). Twelve different time periods for the independent environmental variables were tested against the dependent variable. Six of these periods ended on 1 July, i.e. the start of the time period for the dependent variable and 6 ended on 30 September, i.e. the end of the time period for the dependent variable. The periods tested were 3, 4, 5, 7 and 11 mo prior to the end date and from 1 January of the previous year to either 1 July or 30 September. All data were normalised so that they had a mean of zero and a standard deviation of 1 .

The last $4 \mathrm{yr}$ in the data set were chosen for validation and the combination of a reduction in both the root mean square error (RMSE) for the calibration set and the RMSE for the validation set were used to select the set of variables for the PLS regression. The analysis was done in MATLAB ${ }^{\circledR}$ using a PLS programme package from Eigenvector ${ }^{\circledR}$.

The relationship between DPP (expressed in percent of total water column PP) and the average saturation of oxygen in the PBL was analysed by correlating the 2 parameters directly. Values were from the months of July to September during the time period from 1999 to 2012 (excluding 2004 and 2009 when data was not available). 


\section{RESULTS}

\section{Primary production in Aarhus Bight: 1999 to 2012}

The annual average for total water column PP in Aarhus Bight over the period from 1999 to 2012 was $155 \pm 38 \mathrm{~g} \mathrm{C} \mathrm{m}^{-2} \mathrm{yr}^{-1}$. The highest monthly PP was found during August $\left(24 \mathrm{~g} \mathrm{C} \mathrm{m}^{-2} \mathrm{mo}^{-1}\right.$, Fig. 2a). In contrast, the chl a concentration (integrated over the entire water column) exhibited relatively low values during the months from April to September. The average concentration of chl a peaked during spring (March) and autumn (November) (Fig. 2a). Integrated chl a concentrations were consistently low during the months when PP and DPP were high (see below).

DPP contributed on average $21 \%( \pm 6 \%)$ of the annual PP from 1999 to 2012 (Fig. 2b). The occurrence of a stratified water column meeting the density criterion $\left(\Delta \rho / \Delta z>1 \mathrm{~kg} \mathrm{~m}^{-4}\right)$ was most frequent between April and September. June had the highest frequency of days with a stratified water column (96\%, Fig. 2b). The magnitude of DPP was relatively constant throughout the summer months of June, July and August (mean $6.5 \pm 0.7 \mathrm{~g} \mathrm{C} \mathrm{m}^{-2} \mathrm{mo}^{-1}$, Fig. 2b). As a percentage of total PP, DPP was most important in June (36\%) and July (34\%).

The $P$ vs. $E$ parameters showed significantly higher chlorophyll-normalised $P_{\max }$ values $\left(P_{\max }{ }^{B}\right)$ in the surface layer than in the PBL ( $t$-test, $t=4.03, \mathrm{p}<0.0001$ ). This difference was also found for the light intensity at which photosynthesis is initially saturated, $I_{k}$ ( $t$-test, $t=9.22, \mathrm{p}<0.0001)$. The opposite was true for the chlorophyll-specific $\alpha\left(\alpha^{B}\right)$ values. Here, samples from the PBL showed significantly higher values than samples from the surface layer ( $t$-test $t=-2.64, \mathrm{p}<0.01$ ).

The average PAR for the water column from 0 to $10 \mathrm{~m}$ was $6.8 \mathrm{~mol} \mathrm{~m}^{-2} \mathrm{~d}^{-1}$ (highest in June and July, average $=13.8$ ) and $0.64 \mathrm{~mol} \mathrm{~m}^{-2} \mathrm{~d}^{-1}$ at the depth of Sample 2 in the PBL. The monthly average PAR intensity at the depth of Sample 2 varied from 1.7 to $4.4 \%$ of surface $(0.1 \mathrm{~m})$ values and never went below $1 \%$. Thus, the second sample depth was placed within the euphotic zone.

The average DIN concentration at $1 \mathrm{~m}$ was low from March to October and the average DIP concentration was low from March to September. The bottom water concentrations never went below 2 and $0.2 \mu \mathrm{mol} \mathrm{l}^{-1}$ for DIN and DIP, respectively (Fig. 2c). A significant negative relationship was found between the average monthly PP and the average monthly concentration of DIN for the entire water column $(r=-0.77, p<0.005$, $\mathrm{n}=12$ ). A similar relationship was found for water column PP and DIP $(r=-0.85, \mathrm{p}<0.001)$.
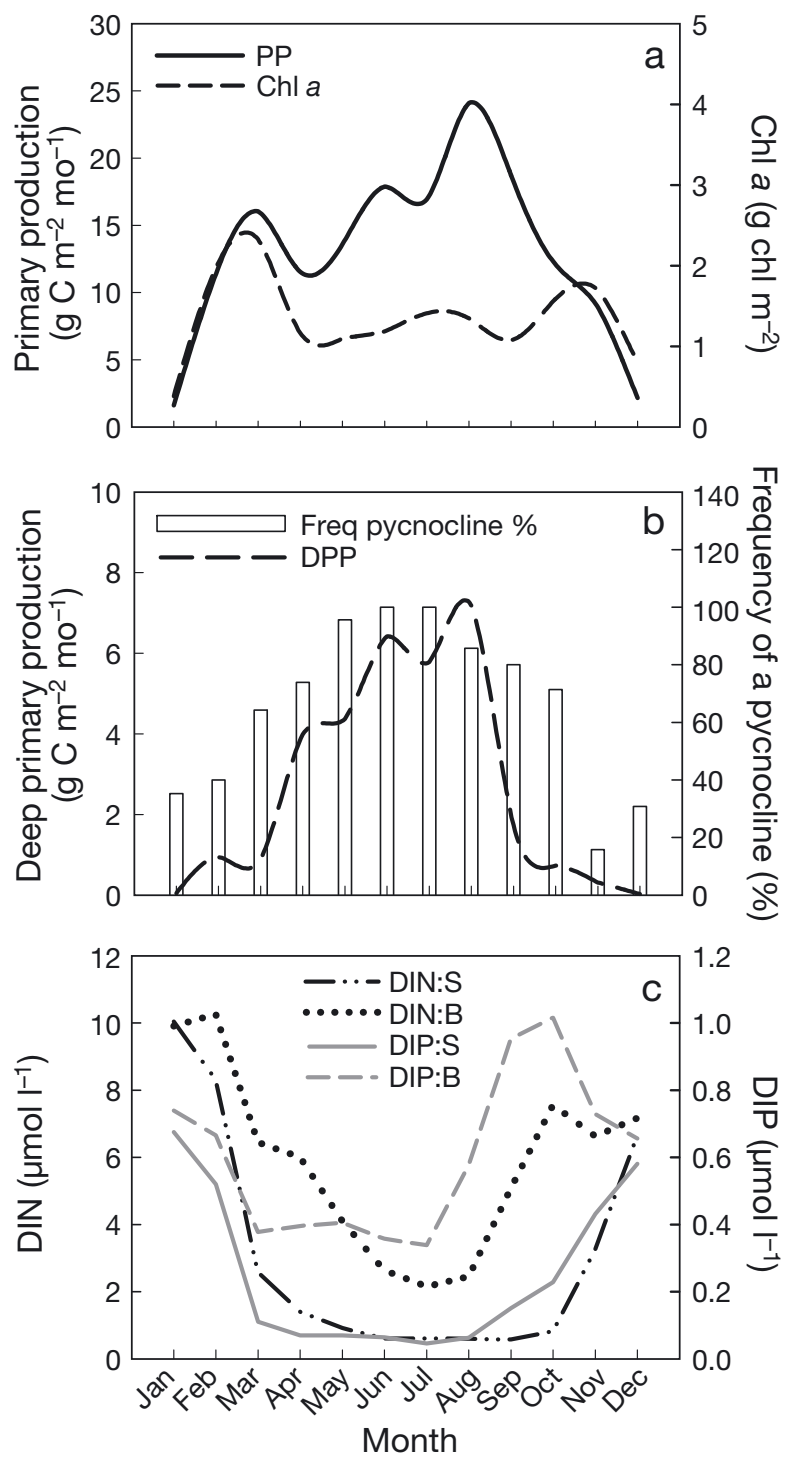

Fig. 2. Seasonal variation of average monthly values from 1999 to 2012 for the station in Aarhus Bight. (a) Monthly primary production (PP) and depth-integrated monthly chl a. values. (b) Deep primary production (DPP) and frequency of days with a distinct pycnocline-bottom layer $(\Delta \rho / \Delta z>1 \mathrm{~kg}$ $\mathrm{m}^{-4}$ ). (c) Average dissolved inorganic nitrogen (DIN) and phosphate (DIP) concentration for the surface waters (S) at $1 \mathrm{~m}$ (DIN: S, DIP: S) and for bottom waters (B) from 10 to 16.6 m (DIN: B, DIP: B)

\section{Oxygen saturation in the PBL}

Through the PLS regression and the variable selection, we found that average salinity (surface layer i.e. above the PBL) from March to September, light attenuation coefficient $\left(K_{\mathrm{d}}\right)$ from June to September, P-loading from August (the year before) to June, and wind from January to June explained the greatest proportion of the variability in oxygen concentration 


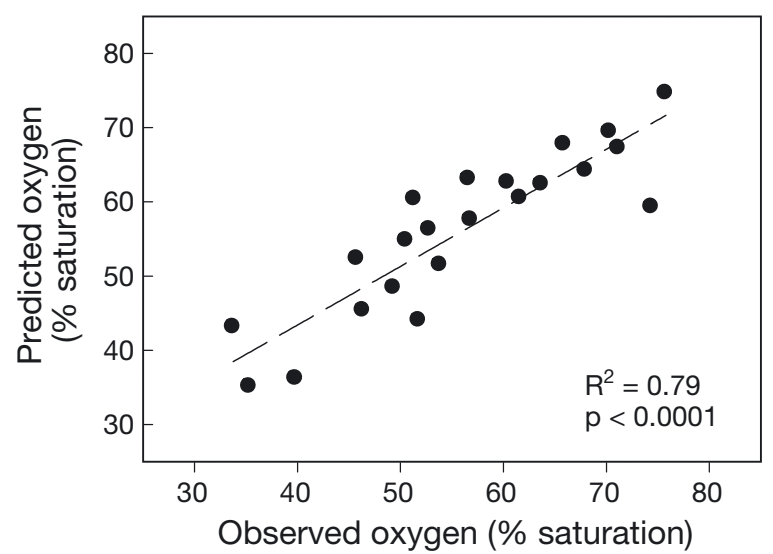

Fig. 3. Partial least square (PLS) regression for prediction of oxygen saturation in the pycnocline-bottom layer (PBL) during late summer (July to September) in Aarhus Bight from 1991 to 2012. Salinity is average salinity in the water above the pycnocline from March to September and the average attenuation coefficient $\left(K_{\mathrm{d}}\right)$ from June to September. Phosphate (P) loading is from August (the year before) to June and wind is from January to June. The intercept is $11.8 \%$. Averages are time weighted and all data are normalised (mean $=0$ and $\mathrm{SD}=1)$. The regression is based on 4 variables each with the following coefficients: salinity $=0.52$, $K_{\mathrm{d}}=-0.05$, P-loading $=-0.65$, and wind $=0.48$

in the PBL (Fig. 3). All of the 4 variables increased the model's ability to predict the average oxygen saturation in the PBL from July to September. The normalised PLS correlation coefficient showed that oxygen in the PBL was positively correlated with salinity in the surface layer (coefficient of 0.52) and wind (coefficient of 0.48), and negatively correlated with $K_{\mathrm{d}}$ (coefficient of -0.05 ) and P-loading (coefficient of 0.65 ), which means that oxygen saturation was positively coupled to clear water, high salinity and strong winds, and negatively affected by high P-loading from land. The PLS regression model showed a fit of $\mathrm{R}^{2}=0.79$ (Fig. 3). When the PLS regression was run with only 2 variables, $K_{\mathrm{d}}$ and salinity, it showed a model fit of $\mathrm{R}^{2}=0.6$, and their respective coefficients were higher (salinity $=0.59$ and $K_{\mathrm{d}}=-0.38$ ), suggesting that P-loading and water transparency are connected.

The surface layer salinity and $K_{\mathrm{d}}$ were significantly and negatively correlated $\left(\mathrm{R}^{2}=0.01, \mathrm{p}<0.05, \mathrm{n}=\right.$ $371)$, whereas the PBL salinity and $K_{\mathrm{d}}$ showed no relationship. This means that the surface layer salinity was most important in the prediction of $K_{\mathrm{d}}$, whereas the PBL salinity did not seem to have any explanatory effect. A linear regression between the average salinity of the surface layer and the average salinity of the PBL, including the months from June to September and years from 1991 to 2012, showed that

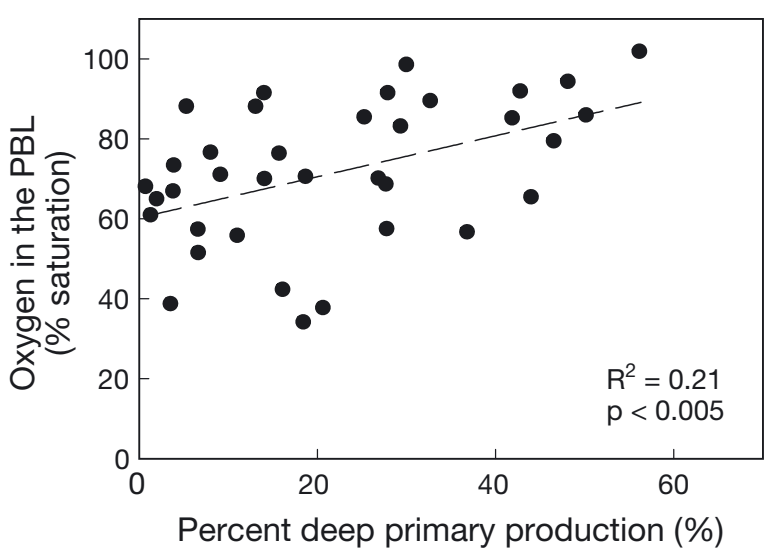

Fig. 4. Oxygen saturation in the pycnocline-bottom layer (PBL, \%) as a function of deep primary production (\% of total water column) during the months from July to September from 1999 to 2012. A linear regression of the 2 parameters shows a significant and positive relationship $\left(\mathrm{R}^{2}=0.21, \mathrm{p}<\right.$ 0.005)

they were significantly and positively related $\left(R^{2}=\right.$ $0.38, \mathrm{p}<0.0001, \mathrm{n}=368$ ). This means that changes in PBL salinity were influenced by changes in surface water salinity. Whether changes in salinity were due to advective processes, mixing between layers or runoff from land was not examined.

The negative impact that P-loading has on the oxygen saturation in the PBL is most likely due to increased growth and production of organic material in the surface layer, which uses oxygen when decomposing on the sediment floor. $\mathrm{N}$ - and P-loading are correlated; thus, a relationship with either must be interpreted as being related to nutrient loading more generally. In this case, N-loading was also tested in the PLS regression but showed a lower explanatory power than P-loading. We, therefore, focused on Prather than $\mathrm{N}$-loading for this part of the study. A positive correlation between P-loading and $K_{\mathrm{d}}(\mathrm{r}=0.61$, $\mathrm{p}<0.01, \mathrm{n}=22$ ) was found, suggesting that production stimulated by P-loading in the surface layer decreases the amount of light entering the PBL. In addition, the average oxygen saturation in the PBL (July to September, 1999 to 2012) was significantly and positively correlated with the fraction of DPP occurring in this layer during the same time period (Fig. 4).

\section{Field study in Aarhus Bight: 2010}

At the time of the field study in July 2010, the water column was characterised by strong stratification, with the starting depth of the PBL ranging from about 6 to $12 \mathrm{~m}$ (Fig. 5a,e). There was gener- 

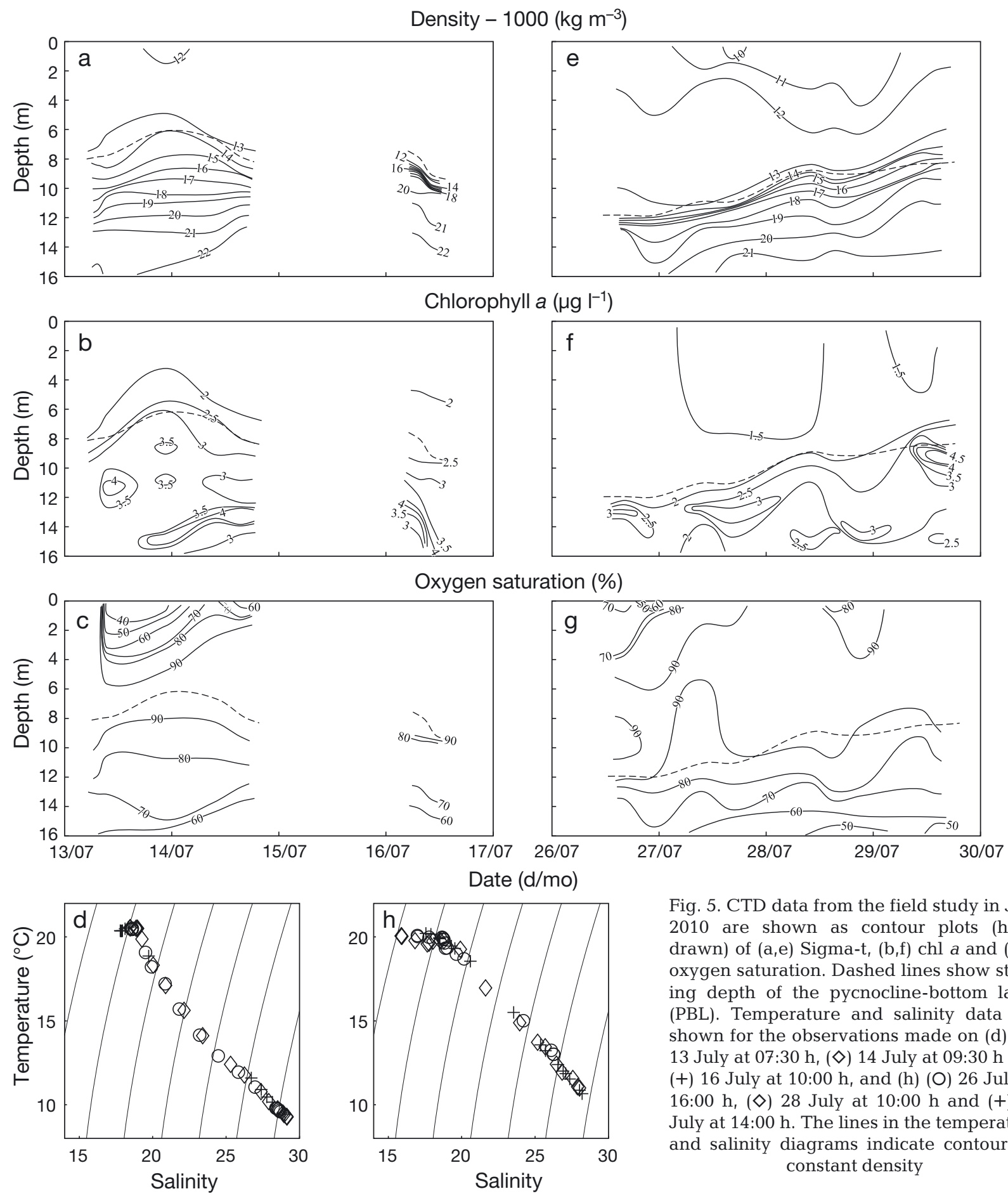

Fig. 5. CTD data from the field study in July 2010 are shown as contour plots (hand drawn) of $(\mathrm{a}, \mathrm{e})$ Sigma-t, $(\mathrm{b}, \mathrm{f}) \mathrm{chl} \mathrm{a}$ and $(\mathrm{c}, \mathrm{g})$ oxygen saturation. Dashed lines show starting depth of the pycnocline-bottom layer (PBL). Temperature and salinity data are shown for the observations made on (d) (O) 13 July at 07:30 $h,(\diamond) 14$ July at 09:30 $\mathrm{h}$ and (+) 16 July at 10:00 h, and (h) (O) 26 July at 16:00 h, $(\diamond) 28$ July at 10:00 $\mathrm{h}$ and (+) 29 July at 14:00 $\mathrm{h}$. The lines in the temperature and salinity diagrams indicate contours of constant density

ally a higher concentration of chl $a$ in the PBL than in the surface layer. In addition, during the first week, there were patches of chl a centred on the $1022 \mathrm{~kg} \mathrm{~m}^{-3}$ isopycnal, i.e. in the upper region of the PBL (Fig. 5b, starting depth of PBL is marked with a dashed line). During the last half of the study, chl $a$ patches were concentrated on the $1019 \mathrm{~kg} \mathrm{~m}^{-3}$ isopycnal, also in the upper region of the PBL (Fig. 5f).

Oxygen saturation was highest in the region of the layer just above and around the starting depth of the PBL (Fig. 5c,g). The distribution of oxygen saturation did not specifically track the distribution of the chl a concentration, although both were highest in the 


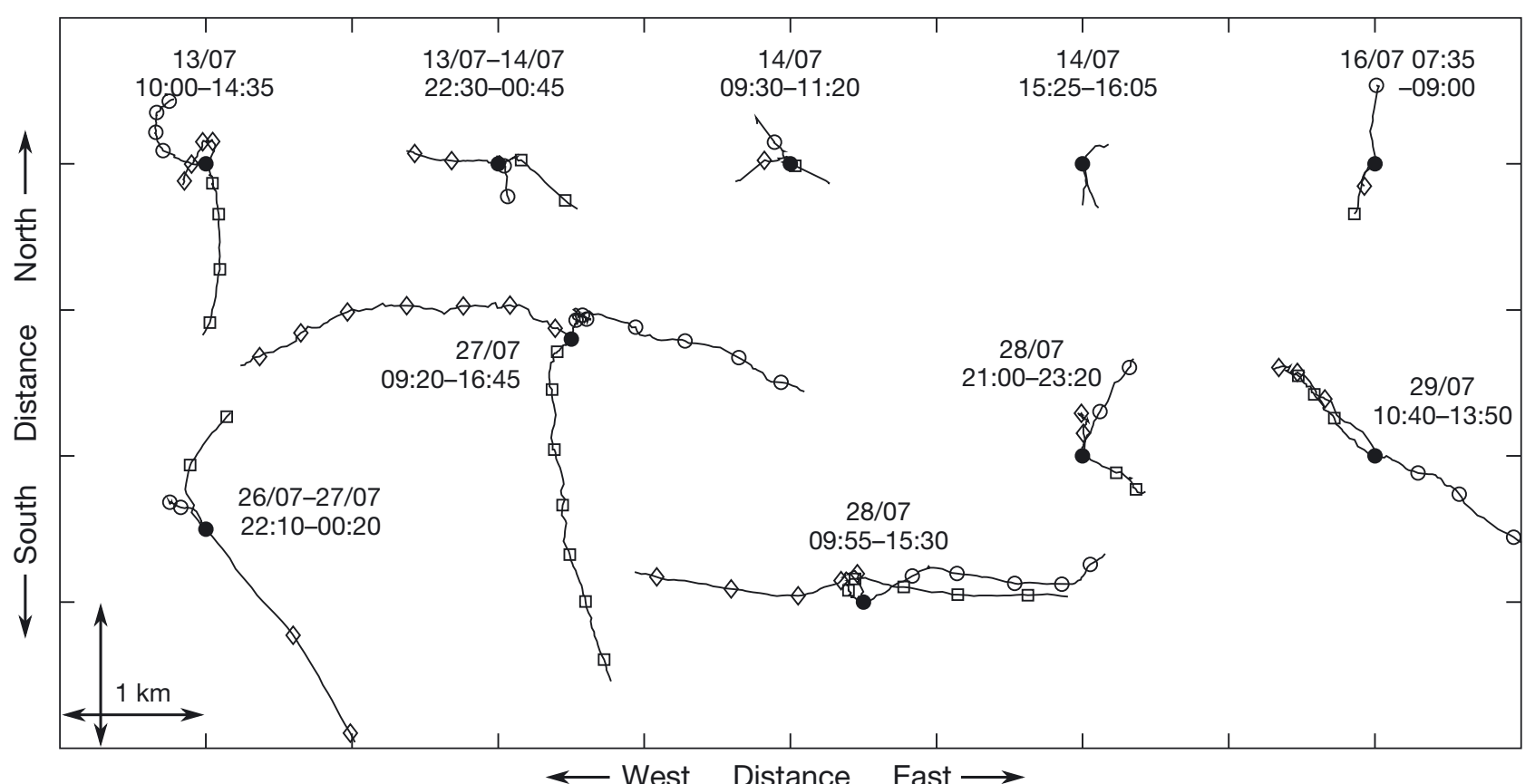

Fig. 6. Progressive vector plots of the water masses in the depth intervals: (O) 3 to $5 \mathrm{~m},(\square) 8$ to $10 \mathrm{~m}$ and ( $\diamond) 13$ to $15 \mathrm{~m}$ based on Acoustic Doppler Current Profiler (ADCP) observations. The plots cover a total of 10 periods where additional water sampling was carried out. For each period the plots start at the solid circle and show the movements of the water masses in time relative to that point. The markers are placed at a time interval of $1 \mathrm{~h}$, allowing the average flow speed to be calculated by measuring the distance in between the symbols. The periods are indicated on the plots as dates $(\mathrm{d} / \mathrm{mo})$ and time $(\mathrm{h})$

region of the PBL-starting depth, which again, had concentrations higher than those found near the bottom.

Temperature and salinity (TS) diagrams (Fig. 5d,h) show 2 distinct clusters of data points associated with surface and bottom waters, respectively. This suggests that only 2 end-members were present and indicates that the horizontal gradient in the water mass properties in the area was small. However, the baroclinic forcing was strong, showing flows in different directions in different parts of the water column. Fig. 6 shows the data from the ADCP as a progressive vector plot during sampling periods where direction and flow velocity at different depth intervals can be read off the figure directly. Typical flow speeds were $0.1 \mathrm{~m} \mathrm{~s}^{-1}$ or less, with a few examples of higher flow speeds, e.g. 26 July during the night, when the bottom water velocity was flowing at approximately $0.26 \mathrm{~m} \mathrm{~s}^{-1}$ in a south-easterly direction.

This and several other examples of substantial flow in the lower or middle parts of the water column are probably closely connected with changes in the baroclinic pressure field to the south, i.e. at the open boundary of Aarhus Bight. Such changes are likely to occur frequently in connection with changes in the overall flow between the Kattegat and the Baltic, which may relatively quickly drive either low-saline water masses of the Baltic or high-saline water masses of the Kattegat into the area (Gustafsson 1997).

The deepest water layer is interesting for the evaluation of possible resuspension into the deepest sediment traps $(14 \mathrm{~m})$, and the depth intervals from the upper water column ( 3 to $5 \mathrm{~m}$ and 8 to $10 \mathrm{~m}$ ) are interesting for the evaluation of the importance of advection for changes in standing stock and oxygen conditions. The progressive vector plot does not show any general or consistent flow direction and velocity.

\section{Phytoplankton}

On all sampling dates in the study, the taxonomic composition of the phytoplankton population in the surface layer differed considerably from that found in the PBL. On all but 1 sampling date (14 July), the diatom Proboscis alata dominated in the surface waters while the PBL community was characterised by a high abundance of dinoflagellates, particularly Ceratium spp. Several species were specific to the water layer in which they were found, i.e. never present in the other layer (Table 1). The number of species 
Table 1. Phytoplankton species found exclusively either at $1 \mathrm{~m}$ depth or in the pycnocline-bottom layer (PBL). The samples analysed were taken on 6 different days during the period from 13 to 29 July 2010

\begin{tabular}{|ll|}
\hline Class & Species \\
\hline $\mathbf{1}$ m only & \\
Dinophyceae & $\begin{array}{l}\text { Alexandrium pseudogonyaulax } \\
\text { Prorocentrum minimum } \\
\text { Aphanizomenon sp. } \\
\text { PBL only }\end{array}$ \\
Dinophyceae & $\begin{array}{l}\text { Ceratium lineatum } \\
\text { Ceratium longipes/horridum } \\
\text { Ceratium macroceros } \\
\text { Dinophysis acuminate } \\
\text { Dinophysis norvegica } \\
\text { Protoperidinium oblongum } \\
\text { Guinardia flaccida } \\
\text { Diatomophyceae }\end{array}$ \\
Chrysophyceae & Dictyochlum (+skeleton) \\
\hline
\end{tabular}

found exclusively in the PBL (15 to 18 species) on any given day was higher than the number of species found exclusively at $1 \mathrm{~m}$ ( 7 to 14 species). In total, 20 to 26 different species were identified from water samples taken at $1 \mathrm{~m}$ and 24 to 36 different species from the deep samples. Thus, both species richness (i.e. the total number of species) and the number of species exclusively found in a specific layer were highest for the deep samples. The carbon biomass of the species found exclusively in the surface layer was only $3.4 \%$ of the total carbon biomass found in this layer, with the highest contribution coming from Alexandrium pseudogonyaulax $(2.7 \%)$. In the PBL, the percent of the total biomass coming from species only found in that layer was $47 \%$, with the highest contributions coming from $C$. lineatum $(26 \%), C$. longipes $(10 \%)$, and Dinophysis norvegica $(9.4 \%)$. The remaining species that were unique to this layer each constituted less than $1 \%$ of the total carbon biomass found in the PBL.

The photosynthesis characteristics for phytoplankton from $1 \mathrm{~m}$ and in the PBL (Table 2) indicate that the communities were segregated. Samples from $1 \mathrm{~m}$ showed a higher chlorophyll-normalised $P_{\max }$ than samples taken from the PBL. This has previously been found in the Celtic and Irish Sea with similar $P_{\max }$ values (Moore et al. 2006). Phytoplankton from the PBL generally exhibited a similar or greater chlorophyll-specific $\alpha$ value $\left(\alpha^{\mathrm{B}}\right)$ than phytoplankton from the surface waters at $1 \mathrm{~m}$ depth but the difference between the 2 layers was not significant.

The $I_{k}$ values (Table 2) were significantly higher for phytoplankton at $1 \mathrm{~m}$ compared to phytoplankton from the PBL $(t=9.22, \mathrm{df}=9, \mathrm{p}<0.0001)$. The irradiance, PAR, reaching the depth of Sample 2 in the PBL was, on average, $7.5 \%$ of surface values $(0.1 \mathrm{~m})$ during the field study and it never went below $1 \%$ even as deep as $15 \mathrm{~m}$. The average PAR at $1 \mathrm{~m}$ was $28.9 \pm$ $1.9 \mathrm{~mol} \mathrm{~m}^{-2} \mathrm{~d}^{-1}$ and $3.6 \pm 1.4 \mathrm{~mol} \mathrm{~m}^{-2} \mathrm{~d}^{-1}$ at the depth of Sample 2 (Table 2).

Carbon to chlorophyll ratios were expected to show highest values in samples from $1 \mathrm{~m}$ because the content of chl a has been shown to decrease with increasing light intensities (Cullen 1982). The values found in this study were, however, highest in the water samples from the DCM on 13, 28 and 29 July. This pattern was not consistent, but in each of the

Table 2. Carbon biomass $\left(\mu \mathrm{g} \mathrm{C} \mathrm{l}^{-1}\right.$ ) for diatoms, dinoflagellates and 'other' (i.e. all remaining phytoplankton groups), the carbon to chlorophyll ratio $\left(\mathrm{C}: \mathrm{chl}, \mathrm{g} \mathrm{g}^{-1}\right)$ and $P$ vs. $E$ parameters: chlorophyll-normalised maximum photosynthesis $\left(P_{\max }{ }^{\mathrm{B}}, \mathrm{mg} \mathrm{C}^{\mathrm{C}} \mathrm{mg}^{-1} \mathrm{chl}\right.$ $\left.\mathrm{h}^{-1}\right)$ and slope of the initial $P$ vs. $E$ curve $\left(\alpha^{\mathrm{B}}, \mathrm{mg} \mathrm{C} \mathrm{mg}^{-1} \mathrm{chl} \mathrm{mol}^{-1} \mathrm{~m}^{2}\right)$, and the light intensity at which photosynthesis is initially saturated $\left(I_{k}, \mu \mathrm{mol}\right.$ photons $\left.\mathrm{m}^{-2} \mathrm{~s}^{-1}\right)$ are shown for samples from $1 \mathrm{~m}$ depth and from the pycnocline-bottom layer (PBL) on each sampling date. Average daily photosynthetically active radiation (PAR) is shown in actual values (mol m $\mathrm{m}^{-2}$ ) and as percent of surface $(0.1 \mathrm{~m})$ values. Sign. = significant differences (Sign., $t$-test) between values found at the 2 different layers, ${ }^{*} p<0.05$, ${ }^{* * *} \mathrm{p}<0.0001, \mathrm{~ns}=$ not significant. - : not tested

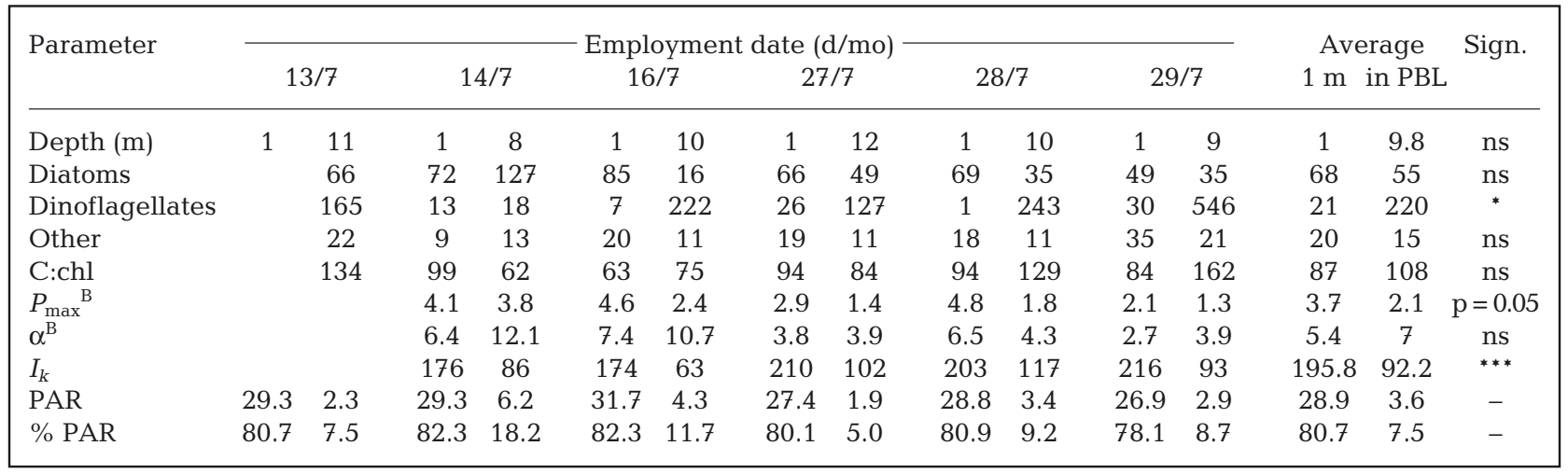



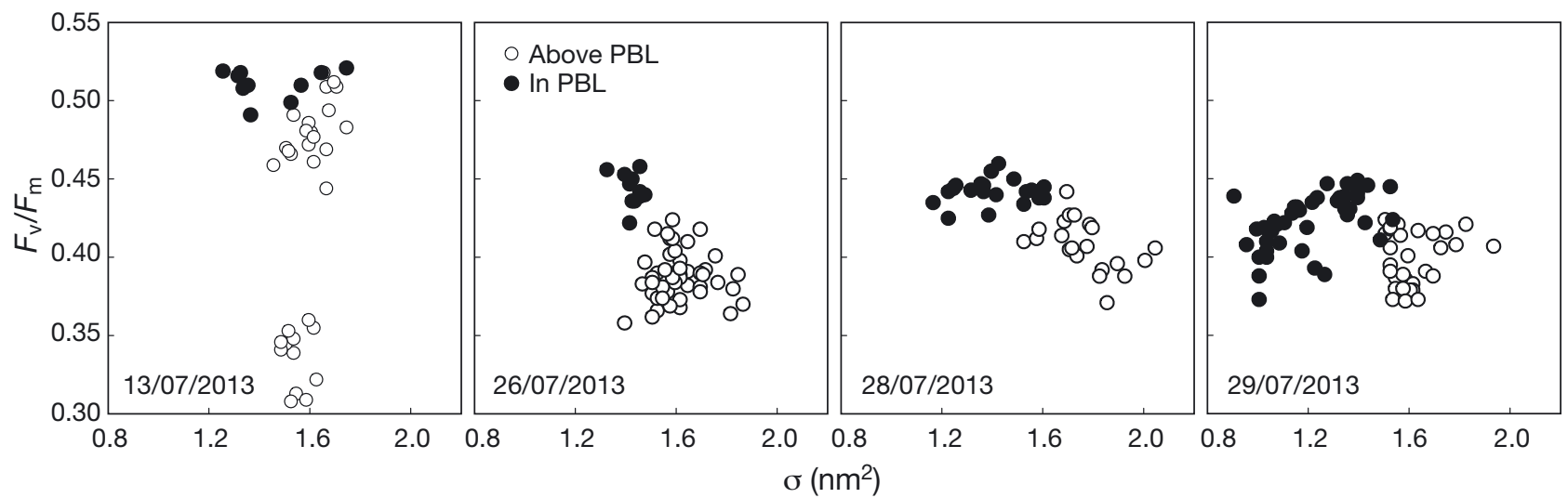

Fig. 7. Variable fluorescence $\left(F_{\mathrm{v}} / F_{\mathrm{m}}\right)$ as a function of the effective cross section in photosystem II ( $\left.\sigma_{\mathrm{PSII}}\right)$ for the 4 night profiles measured during the July 2010 field study. Values are from the waters (O) above the pycnocline-bottom layer (PBL) and ( in the PBL. Dates are d/mo/yr

deep samples exhibiting a higher carbon to chlorophyll ratio than that of surface samples, there was a large biomass of the dinoflagellates $C$. lineatum, $C$. tripos, $C$. longipes and $D$. norvegica.

Profiles of normalised variable fluorescence showed a consistent pattern of lower values for the effective absorption cross-section of photosystem II $\left(\sigma_{\mathrm{PSII}}\right)$ and higher values of $F_{\mathrm{v}} / F_{\mathrm{m}}$ in the PBL than in the surface layer (Fig. 7). This supports the conclusion that there were photosynthetically active phytoplankton in the PBL and that the cells here were, generally, larger than those in the surface waters. The higher $\sigma_{\mathrm{PSII}}$ in the surface waters than in the PBL indicates the presence of smaller cells there than in the deeper waters. Size-fractionated chl a also indicated that large cells were more abundant in the PBL than in the surface layer (Fig. 8).

\section{Sedimentation}

The highest sedimentation rates were consistently found in the deepest samples (Table 3, Fig. 8). The velocity of sinking particulate organic $\mathrm{C}$ at $14 \mathrm{~m}$ was 2.4 to 4 times greater than sinking rates at $6 \mathrm{~m}$. The pattern of nitrogen sedimentation mirrored that of carbon and the sinking rate increased by a factor of 2.1 to 3.4 between 6 and $14 \mathrm{~m}$. Thus, we consistently found that the material produced in the surface waters sank more slowly than the material in the PBL ( $t$-test, $t=$ $-2.42, \mathrm{df}=12, \mathrm{p}=0.032$ ).
Primary production $\left(\mathrm{mg} \mathrm{C} \mathrm{m}^{-3} \mathrm{~d}^{-1}\right)$

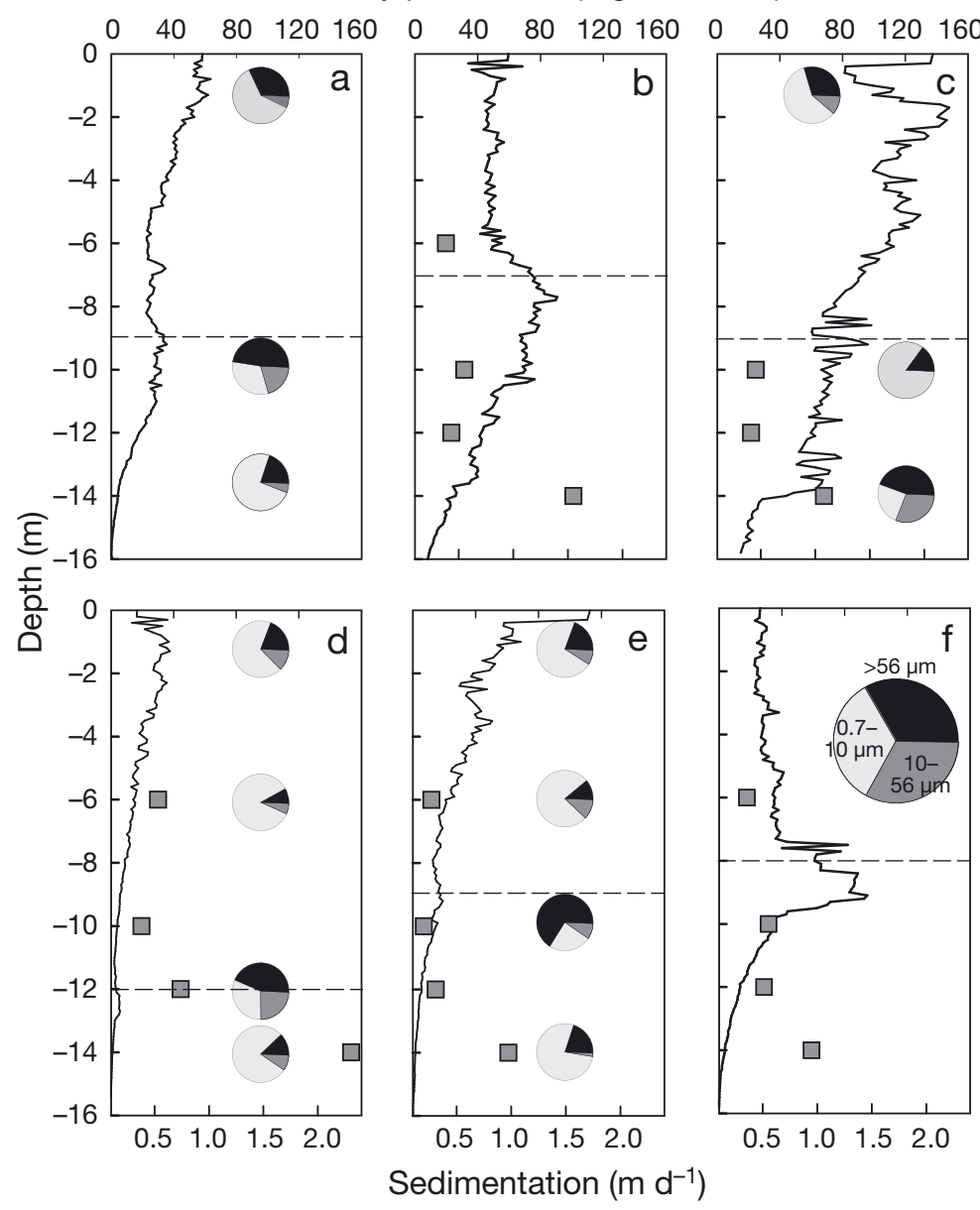

Fig. 8. Depth profiles of primary production on 6 different days with pie charts illustrating the distribution of size-fractionated chl a (\%) and sinking rates of carbon (ם). Size-fractionated chl a values represent the \% of the total chlorophyll in the sample that was retained on GF/F (nominally $0.7 \mu \mathrm{m}$ ) (light grey), $10 \mu \mathrm{m}$ (dark grey) and $56 \mu \mathrm{m}$ (black) filters, respectively. The pie charts are placed at the correct sample depths. Dashed line: starting depth of the pycnocline-bottom layer 
Table 3. Sinking rate $\left(\mathrm{m} \mathrm{d}^{-1}\right)$ for particulate carbon and nitrogen at different depths during the $5 \mathrm{~d}$ of sediment trap employments. Average values for the waters in and above the pycnocline-bottom layer (PBL) are noted in the 2 columns on the right. The values of carbon sinking rates above the PBL are significantly lower than the ones found in the PBL $(t=-2.42, \mathrm{df}=12$,

$$
\mathrm{p}<0.05) .{ }^{*} \mathrm{p}<0.05
$$

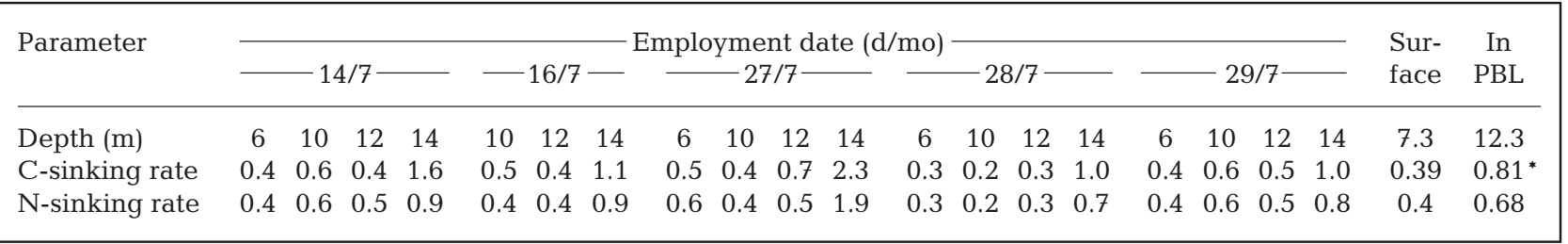

Pictures of trap material (not shown) from the PBL showed a high number of faecal pellets and of phytoplankton cells of species from the Ceratium genus. No sand grains were observed in the pictures, suggesting that little re-suspended material was being collected in the traps.

\section{DISCUSSION}

Concerns about eutrophication effects resulting from anthropogenic nutrient enrichment in coastal seas typically focus on changes in total water column PP as opposed to PP in different layers, as it is assumed that changes in total PP will directly lead to changes in the amount of organic material degraded in the system and, hence, oxygen conditions (see Rabalais et al. 2002). This study clearly demonstrates, however, that the fate of photosynthetically produced carbon as well as oxygen conditions in the water column are highly dependent upon the vertical distribution pattern of the PP occurring there.

\section{Influence of photosynthesis on oxygen conditions in the PBL}

Everything else being equal, the amount of photosynthesis occurring in the PBL will be a function of light penetrating to these depths. Lyngsgaard et al. (2014) demonstrated a significant relationship between surface irradiance and the magnitude of DPP in the BSTZ. The analysis presented here demonstrates that changes in surface water salinity (due to changes in runoff, advective processes and/or vertical mixing) and nutrient loading affect the water transparency and, thereby, light conditions in the PBL. Improved water transparency will in turn stimulate the light-limited DPP. Conditions influencing the water transparency in the surface layer are, thus, important in determining the quantity of the DPP.
This is clearly reflected in the PLS regression analysis where $K_{\mathrm{d}}$ has the greatest effect on oxygen saturation in the PBL during the summer months from June to September, when nutrients are limiting and DPP highest. Thus, decreased nutrient loading to the surface layer will stimulate DPP, which again will have a positive effect on the oxygen conditions in the PBL during a time where oxygen depletion has been common in Aarhus Bight.

The PLS regression model included 4 variables, which together explained $79 \%$ of the variation in oxygen saturation in the PBL. The more variables chosen will, however, also increase the model fit, and we, therefore, chose also to run the PLS regression with only 2 variables. This PLS regression showed a poorer fit when a higher explanatory power was given to the water transparency. This suggests that $K_{\mathrm{d}}$ and P-loading are coupled and that water transparency is a key parameter in the prediction of oxygen saturation in bottom waters and is affected by several parameters such as nutrient loading and particle and plankton abundance.

Oxygen saturation in the PBL is, at least initially, a function of physical processes, i.e. advection and vertical mixing (Bendtsen et al. 2009, Hansen \& Bendtsen 2013). Vertical mixing, however, plays a minor role in controlling oxygen conditions in the PBL during late summer, because of the strong water column stratification. As demonstrated in the PLS regression, where wind has the highest explanatory power in winter, spring and early summer from January to June, vertical mixing is most important for oxygen conditions in the PBL during spring and summer, when it is strongest. The oxygen input during summer must, therefore, come from lateral water movement and biological oxygen production taking place in the PBL. The considerable lateral water movement in Aarhus Bight (e.g. as shown in Fig. 6) can cause sudden hypoxia situations (Jørgensen 1996) and complicates the analysis of the relationship between the magnitude of DPP and oxygen saturation in the 
PBL, e.g. an inflow of a deep, saline water mass from the Kattegat could imply either oxygen rich waters or waters depleted of oxygen. The exchange of water masses is particularly strong in connection with storms in the Kattegat or a change in direction of the current through the Belt Sea (Nielsen et al. 2005). This explains some of the variability that has been observed in the long time series that is the subject of this study.

Despite the importance of lateral water movement for the oxygen saturation in the PBL, there was a significant and positive relationship between the 2 parameters (Fig. 4). This indicates that DPP has a positive effect on the PBL oxygen saturation and makes a quantitatively important contribution to the oxygen conditions. DPP is here estimated to contribute approximately $21 \%$ of the total annual PP occurring at this station during the period from 1999 to 2012.

From this, we can estimate an annual oxygen production in the PBL of $88 \mathrm{~g} \mathrm{O}_{2} \mathrm{~m}^{-2} \mathrm{yr}^{-1}$, assuming a photosynthetic quotient (PQ) of 1 and a total annual PP of $155 \mathrm{~g} \mathrm{C} \mathrm{m}^{-2} \mathrm{yr}^{-1}$. The oxygen demand in the bottom layer has been estimated to vary from $48.8 \%$ (Bendtsen \& Hansen 2013) to $58 \%$ (Fossing et al. 2002) of PP. Using these values, DPP can be estimated to contribute 37 to $44 \%$ of the annual oxygen demand in the PBL in Aarhus Bight. Note that this study does not differentiate between the pycnocline layer and the bottom layer, and the transport of oxygen from the pycnocline and into the bottom layer remains to be quantified. Nevertheless, during April to August, the PP in the deepest $5 \mathrm{~m}$ of the water column (from 11 to $16 \mathrm{~m}$ ) contributes, on average, 15\% to the total water column PP, which indicates that a considerable amount of PP does take place in the near-bottom layer. Benthic PP has not been addressed in this study but has previously been shown to be of considerable magnitude in areas where light reaches the sediment floor (Krause-Jensen et al. 2012). This would form an additional $\mathrm{O}_{2}$ source in bottom waters.

In addition to producing oxygen, DPP creates organic material. The degradation of this material will contribute to the respiratory oxygen demand in the PBL following the sinking of the material. However, in contrast to organic material produced in surface waters and sinking to the bottom waters, the oxygen necessary for the degradation of material produced in the bottom waters is compensated for by the oxygen produced by the photosynthesis producing the material in the same layer. Thus, it becomes important when considering the relationship between PP and bottom water oxygen conditions to dif- ferentiate between different layers in the water column.

\section{Phytoplankton communities and production characteristics change when entering the deep layer}

Several lines of evidence (i.e. species taxonomy, cell size, variable fluorescence, photosynthetic parameters and water movements) support our initial hypothesis that the water column is segregated into different layers, not only physically but also with respect to ecosystem functioning. The photosynthetic and optical parameters recorded from the phytoplankton communities retrieved during the July 2010 field study from surface waters and the PBL indicate 2 actively photosynthesising populations, each adapted to the specific light characteristics of the water layer in which they are found (for discussion of light adaptation/acclimatisation see, for example, Lindley et al. 1995, Morán \& Estrada 2001) and were within the range of previously measured $P$ vs. $E$ parameters from other temperate oceans (Moore et al. 2006). The relatively high $F_{\mathrm{v}} / F_{\mathrm{m}}$ values recorded in the PBL support the conclusion that the phytoplankton here were physiologically active and capable of photosynthesis.

Direct comparison of variable fluorescence characteristics between the surface waters and the PBL is complicated by the fact that cell size and taxonomic composition of the community (Suggett et al. 2009) and nutrient status (Beardall et al. 2001) have been shown to influence both $F_{\mathrm{v}} / F_{\mathrm{m}}$ and the effective cross section in photosystem II. We attribute the higher $F_{\mathrm{v}} / F_{\mathrm{m}}$ and lower $\sigma_{\mathrm{PSII}}$ values found in the PBL relative to the surface to be an indication of a better nutrient status and a shift in cell size from small to larger cells (Suggett et al. 2009).

A number of species were characteristic of one specific layer and never encountered in the other layer (Table 1). Such distinct vertical stratification in species distributions where dinoflagellates are abundant in the PBL has been noted earlier in Aarhus Bight (Mouritsen \& Richardson 2003).

Many of the phytoplankton recorded in the PBL are known mixotrophs (see Stoecker 1999, Jeong et al. 2010 and references in these papers). That mixotrophy may be an important nutritional strategy of the community in the PBL may explain the relative high carbon to chl a ratios found here on some sampling dates. Dinoflagellates have been shown to contribute more to the carbon than the chlorophyll biomass because they have a high carbon to chlorophyll 
ratio (Geider 1987, Tang 1996). For strictly autotrophic communities which depend on their ability to harvest and utilise light, these carbon to chlorophyll ratios would have been expected to be lower as decreasing light intensities have been inversely related to increases in the amount of chlorophyll per cell (Kiefer et al. 1976, Cullen 1982, Falkowski \& Kiefer 1985, Fennel \& Boss 2003). Mixotrophy might also be part of the explanation for why the photosynthesis to biomass ratio, $P: B$, was considerably lower in the PBL $(0.008$ to 0.25 , mean $=0.1)$ than in the surface $(0.17$ to 0.63 , mean $=0.38)$.

\section{Importance of DPP versus SPP for sinking characteristics of particulate material}

We would expect (Smayda 1969) the large phytoplankton in the PBL to sink more quickly than the smaller cells in the surface layer, and indeed, the patterns of sedimentation rates recorded in the field study reported here suggest this to be the case. We recognise that there can be problems that complicate interpretation of sediment studies made in shallow waters (Buesseler 1991). However, increased sedimentation rates from the PBL have been observed before in Aarhus Bight (Jørgensen 1996), and we believe that our conclusion of increased sedimentation in the PBL is robust for a number of reasons.

Re-suspension of bottom material into sediment traps would be the greatest concern in interpreting our results. Lund-Hansen et al. (1999) suggested that the bottom current velocity must be higher than $0.1 \mathrm{~m} \mathrm{~s}^{-1}$ to actually lift the organic material from the bottom, and Bloesch \& Burns (1980) state that it has to be $<0.14 \mathrm{~m} \mathrm{~s}^{-1}$ in order to avoid re-suspension into the deep sediment traps. The average bottom flow speeds were well below $0.14 \mathrm{~m} \mathrm{~s}^{-1}$ in this study except during the late night on 26 July, when the bottom flow speed was $0.26 \mathrm{~m} \mathrm{~s}^{-1}$.

The high flow rates might have affected the sedimentation results presented in Fig. 8d, i.e. overestimation of the deepest sedimentation velocity. However, the general lack of sand grains in photographed material from all deep sediment traps indicates that re-suspension was not likely to be controlling the sediment trap results.

\section{Implications for ecology}

The large amount of faecal pellets found in the sediment traps placed in this study in the PBL compared to those in the surface waters suggests that the population in the PBL was being actively grazed, as previously suggested by Nielsen et al. (1993). It seems likely, however, that not all components of the PBL community were actively grazed. Several grazers have been shown to avoid the large Ceratium species (Falkowski et al. 1980 and references therein) and these have been shown in other studies to sink intact to the sediment floor (Jørgensen 1996). Large particle size increases sedimentation rates (Smayda 1969), and one can, therefore, predict that the larger phytoplankton cell size found in the PBL as well as the presence of faecal pellets would lead to increased sedimentation rates of the material produced in the PBL, as opposed to higher up in the water column. Direct selective sinking of phytoplankton as a response to increased $\mathrm{Si} / \mathrm{N}$ ratios has also been suggested to increase sedimentation rates (Dortch et al. 2001). We did find increased $\mathrm{Si} / \mathrm{N}$ ratios in the PBL (data not shown), but as we found mostly dinoflagellates in the PBL and obtained photographs showing high abundance of Ceratium sp. in PBL traps, we do not believe that selective sinking of diatoms was the main driver of the increased sedimentation in the PBL. The efficient transfer to the bottom of organic material produced in the PBL indicated by enhanced sedimentation from this layer may provide an important food supply for benthic feeders. This, however, remains to be examined.

It is often assumed that total water column $\mathrm{PP}$, as opposed to PP in specific layers, is the most important factor controlling the plankton food web and carbon flow in the water column. This study demonstrates, however, that the vertical distribution of PP in the water column is important for both oxygen and carbon dynamics and suggests that there is a need to further quantify seasonal development in the vertical distribution of both phytoplankton species and photosynthesis in order to develop a better understanding of the role of phytoplankton in food webs and biogeochemical cycling.

Acknowledgements. This study received funding from grant number 2104-09-063212 and 2104-09-67259 from the Strategic Research Council of Denmark. Additional support was received from the Center for Macroecology, Evolution and Climate, the Natural History Museum of Denmark, Copenhagen University and the Department for Bioscience, Aarhus University. We thank the Department for Bioscience, Aarhus University for access to the monitoring data and the outstanding crew and captain on the research vessel 'Tyra' for invaluable help and support throughout the field study. Finally, we thank the reviewers for valuable comments and all the people that have been working on the samples from Aarhus Bight over the years. 


\section{LITERATURE CITED}

Beardall J, Young E, Roberts S (2001) Approaches for determining phytoplankton nutrient limitation. Aquat Sci 63: 44-69

Beckmann A, Hense I (2007) Beneath the surface: characteristics of oceanic ecosystems under weak mixing conditions - a theoretical investigation. Prog Oceanogr 75: 771-796

$>$ Bendtsen J, Hansen JLS (2013) Effects of global warming on hypoxia in the Baltic Sea-North Sea transition zone. Ecol Model 264:17-26

> Bendtsen J, Gustafsson KE, Söderkvist J, Hansen JLS (2009) Ventilation of bottom water in the North Sea-Baltic Sea transition zone. J Mar Syst 75:138-149

Benitez-Nelson CR, Bidigare RR, Dickey TD, Landry MR and others (2007) Mesoscale eddies drive increased silica export in the subtropical Pacific Ocean. Science 316: 1017-1021

Bloesch J, Burns NM (1980) A critical review of sedimentation trap technique. Schweiz Z Hydrol 1:1-42

> Buesseler KO (1991) Do upper-ocean sediment traps provide an accurate record of particle flux? Nature 353:420-423

Claustre H, Marty JC (1995) Specific phytoplankton biomasses and their relation to primary production in the tropical North Atlantic. Deep-Sea Res I 42:1475-1493

> Conley DJ, Markager S, Andersen JH, Ellerman T, Svendsen LM (2002) Coastal eutrophication and the Danish national aquatic monitoring and assessment program. Estuaries 25:848-861

Cullen JJ (1982) The deep chlorophyll maximum: comparing vertical profiles of chlorophyll a. Can J Fish Aquat Sci 39:791-803

Dansk Standard (1986) Vandundersøgelse. Klorofyl a. Spektrofotometrisk måling i ethanolekstrakt, inklusive referencer heri. (Water quality - Chlorophyll a - Spectrophotometric determination in ethanol extract, references included) Danish Standard 2201, Danish Standards Foundation, Copenhagen

de Boyer Montégut C, Madec G, Fischer AS, Lazar A, Iudicone D (2004) Mixed layer depth over the global ocean: an examination of profile data and a profile-based climatology. J Geophys Res 109:C12003

Dortch Q, Rabalais N, Turner R, Rowe G (1994) Respiration rates and hypoxia on the Louisiana shelf. Estuaries Coasts 17:862-872

Dortch Q, Rabalais NN, Turner RE, Qureshi NA (2001) Impacts of changing $\mathrm{Si} / \mathrm{N}$ ratios and phytoplankton species composition. In: Rabalais NN, Turner RE (eds) Coastal hypoxia: consequences for living resources and ecosystems. Coastal and Estuarine Studies 58. American Geophysical Union, Washington, DC, p 37-48

> Estrada M, Marrasé C, Latasa M, Berdalet E, Delgado M, Riera T (1993) Variability of deep chlorophyll maximum characteristics in the Northwestern Mediterranean. Mar Ecol Prog Ser 92:289-300

Falkowski PG (1984) Physiological responses of phytoplankton to natural light regimes. J Plankton Res 6:295-307

Falkowski P, Kiefer DA (1985) Chlorophyll a fluorescence in phytoplankton: relationship to photosynthesis and biomass. J Plankton Res 7:715-731

Falkowski PG, Hopkins TS, Walsh JJ (1980) An analysis of factors affecting oxygen depletion in the New York Bight. J Mar Res 38:479-506

Fennel K, Boss E (2003) Subsurface maxima of phytoplank- ton and chlorophyll: steady-state solutions from a simple model. Limnol Oceanogr 48:1521-1534

Fossing H, Thamdrup B, Rysgaard S, Sørensen HM, Nielsen K (2002) Ilt- og næringsstoffluxmodel for Århus Bugt og Mariager Fjord. Modelopsætning og scenarier. Faglig rapport fra DMU, nr. 417, Danmarks Miljøundersøgelser, Miljøministeriet

Furuya K, Marumo R (1983) The structure of the phytoplankton community in the subsurface chlorophyll maxima in the western North Pacific Ocean. J Plankton Res 5: 393-406

> Geider RJ (1987) Light and temperature dependence of the carbon to chlorophyll a ratio in microalgae and cyanobacteria: implications for physiology and growth of phytoplankton. New Phytol 106:1-34

Grasshoff K, Kremling K, Ehrhardt M (1999) Methods of seawater analysis. Wiley-VCH, Weinheim

Gustafsson BG (1997) Interaction between Baltic Sea and North Sea. Dtsch Hydrogr Z 49:165-183

> Hansen JLS, Bendtsen J (2013) Parameterisation of oxygen dynamics in the bottom water of the Baltic Sea-North Sea transition zone. Mar Ecol Prog Ser 481:25-39

Hansen HP, Koroleff F (1999) Determination of nutrients. In: Grasshoff K, Kremling K, Ehrhardt M (eds) Methods of seawater analysis, 3rd edn. Wiley-VCH, Weinheim

Hickman AE, Holligan PM, Moore CM, Sharples J, Krivtsov V, Palmer MR (2009) Distribution and chromatic adaptation of phytoplankton within a shelf sea thermocline. Limnol Oceanogr 54:525-536

- Hickman AE, Moore CM, Sharples J, Lucas MI, Tilstone GH, Krivtsov V, Holligan PM (2012) Primary production and nitrate uptake within the seasonal thermocline of a stratified shelf sea. Mar Ecol Prog Ser 463:39-57

Holligan PM, Williams PJleB, Purdie D, Harris RP (1984) Photosynthesis, respiration and nitrogen supply of plankton populations in stratified, frontal and tidally mixed shelf waters. Mar Ecol Prog Ser 17:201-213

> Holm-Hansen O, Hewes C (2004) Deep chlorophyll-a maxima (DCMs) in Antarctic waters. Polar Biol 27:699-710

> Howarth R, Chan F, Conley DJ, Garnier J, Doney SC, Marino R, Billen G (2011) Coupled biogeochemical cycles: eutrophication and hypoxia in temperate estuaries and coastal marine ecosystems. Front Ecol Environ 9: $18-26$

Jeong H, Yoo Y, Kim J, Seong K, Kang N, Kim T (2010) Growth, feeding and ecological roles of the mixotrophic and heterotrophic dinoflagellates in marine planktonic food webs. Ocean Sci J 45:65-91

Jørgensen BB (1996) Case study-Aarhus Bay. In: Jørgensen BB, Richardson K (eds) Eutrophication in coastal marine ecosystems. Coastal and Estuarine Studies 52. American Geophysical Union, Washington, DC, p 137-154

Kaas H, Markager S (1998) Technical guidelines for marine monitoring. Ministry of Energy and Environment National Environmental Research Institute, Roskilde

Kara AB, Rochford PA, Hurlburt HE (2000) An optimal definition for ocean mixed layer depth. J Geophys Res 105: 16803-16821

Kiefer DA, Olson RJ, Holm-Hansen O (1976) Another look at the nitrite and chlorophyll maxima in the central North Pacific. Deep-Sea Res 23:1199-1208

Klausmeier CA, Litchman E (2001) Algal games: the vertical distribution of phytoplankton in poorly mixed water columns. Limnol Oceanogr 46:1998-2007 
Kolber Z, Zehr J, Falkowski PG (1988) Effects of growth irradiance and nitrogen limitation on photosynthetic energy conversion in photosystem II. Plant Physiol 88:923-929

Kononen K, Huttunen M, Hällfors S, Gentien P and others (2003) Development of a deep chlorophyll maximum of Heterocapsa triquetera Ehrenb. at the entrance to the Gulf of Finland. Limnol Oceanogr 48:594-607

> Krause-Jensen D, Markager S, Dalsgaard T (2012) Benthic and pelagic primary production in different nutrient regimes. Estuaries Coasts 35:527-545

Lehrter JC, Murrell MC, Kurtz JC (2009) Interactions between freshwater input, light, and phytoplankton dynamics on the Louisiana continental shelf. Cont Shelf Res 29:1861-1872

> Lindley ST, Bidigare RR, Barber RT (1995) Phytoplankton photosynthesis parameters along $140^{\circ} \mathrm{W}$ in the equatorial Pacific. Deep-Sea Res II 42:441-463

> Lorenzen CJ (1967) Determination of chlorophyll and pheopigments: Spectrophotometric equations. Limnol Oceanogr 12:343-346

Lund-Hansen LC, Petersson M, Nurjaya W (1999) Vertical sediment fluxes and wave-induced sediment resuspension in a shallow-water coastal lagoon. Estuaries 22: $39-46$

> Lundsgaard C, Olesen M, Reigstad M, Olli K (1999) Sources of settling material: aggregation and zooplankton mediated fluxes in the Gulf of Riga. J Mar Syst 23:197-210

Lyngsgaard MM, Markager S, Richardson K (2014) Changes in the vertical distribution of primary production in response to land-based N-loading. Limnol Oceanogr 59: 1679-1690

> Maar M, Hansen JLS (2011) Increasing temperatures change pelagic trophodynamics and the balance between pelagic and benthic secondary production in a water column model of the Kattegat. J Mar Syst 85:57-70

- Marañón E, Holligan PM, Varela M, Mouriño B, Bale AJ (2000) Basin-scale variability of phytoplankton biomass, production and growth in the Atlantic Ocean. Deep-Sea Res I 47:825-857

> Markager S (1998) Dark uptake of inorganic ${ }^{14} \mathrm{C}$ in oligotrophic oceanic waters. J Plankton Res 20:1813-1836

> Markager S, Vincent WF, Tang EPY (1999) Carbon fixation by phytoplankton in high Arctic lakes: implications of low temperature for photosynthesis. Limnol Oceanogr 44:597-607

> Martin J, Dumont D, Tremblay JE (2013) Contribution of subsurface chlorophyll maxima to primary production in the coastal Beaufort Sea (Canadian Arctic): a model assessment. J Geophys Res 118:5873-5886, doi: 10.1002/2013JC008843

> Moore CM, Suggett DJ, Hickman AE, Kim YN and others (2006) Phytoplankton photoacclimation and photoadaptation in response to environmental gradients in a shelf sea. Limnol Oceanogr 51:936-949

> Morán XAG, Estrada M (2001) Short-term variability of photosynthetic parameters and particulate and dissolved primary production in the Alboran Sea (SW Mediterranean). Mar Ecol Prog Ser 212:53-67

> Mouritsen LT, Richardson K (2003) Vertical microscale patchiness in nano- and microplankton distributions in a stratified estuary. J Plankton Res 25:783-797

- Murrell MC, Campbell JG, Hagy JD III, Caffrey JM (2009) Effects of irradiance on benthic and water column processes in a Gulf of Mexico estuary: Pensacola Bay, Florida, USA. Estuar Coast Shelf Sci 81:501-512
Neumann T (2000) Towards a 3D-ecosystem model of the Baltic Sea. J Mar Syst 25:405-419

Nielsen MH (2005) The baroclinic surface currents in the Kattegat. J Mar Syst 55:97-121

- Nielsen TG, Løkkegaard B, Richardson K, Pedersen FB, Hansen L (1993) Structure of plankton communities in the Dogger Bank area (North Sea) during a stratified situation. Mar Ecol Prog Ser 95:115-131

Nielsen MH, Rasmussen B, Gertz F (2005) A simple model for water level and stratification in Ringkøbing Fjord, a shallow, artificial estuary. Estuar Coast Shelf Sci 63: 235-248

Nixon SW (1995) Coastal marine eutrophication: a definition, social causes, and future concerns. Ophelia 41:199-219

Platt T, Gallegos CL, Harrison WG (1980) Photoinhibition of photosynthesis in natural assemblages of marine phytoplankton. J Mar Res 38:687-701

Rabalais N, Turner RE, Dortch Q, Justic D, Bierman V Jr, Wiseman W Jr (2002) Nutrient-enhanced productivity in the northern Gulf of Mexico: past, present and future. Hydrobiologia 475/476:39-63

- Richardson K, Christoffersen A (1991) Seasonal distribution and production of phytoplankton in the southern Kattegat. Mar Ecol Prog Ser 78:217-227

Richardson K, Beardall J, Raven JA (1983) Adaptation of unicellular algae to irradiance: an analysis of strategies. New Phytol 93:157-191

> Richardson K, Nielsen TG, Pedersen FB, Heilmann JP, Løkkegaard B, Kaas H (1998) Spatial heterogeneity in the structure of the planktonic food web in the North Sea. Mar Ecol Prog Ser 168:197-211

Richardson K, Visser AW, Pedersen FB (2000) Subsurface phytoplankton blooms fuel pelagic production in the North Sea. J Plankton Res 22:1663-1671

Richardson K, Markager S, Buch E, Lassen MF, Kristensen AS (2005) Seasonal distribution of primary production, phytoplankton biomass and size distribution in the Greenland Sea. Deep-Sea Res 52:979-999

Richardson K, Bendtsen J, Christensen JT, Adjou M and others (2014) Localised mixing and heterogeneity in the plankton food web in a frontal region of the Sargasso Sea: implications for eel early life history? Mar Ecol Prog Ser 504:91-107

Riley GA, Stommel HM, Bumpus DF (1949) Quantitative ecology of the plankton of the western North Atlantic. Bull Bingham Oceanogr Collect 12:1-169

Ross ON, Sharples J (2007) Phytoplankton motility and the competition for nutrients in the thermocline. Mar Ecol Prog Ser 347:21-38

> Sedwick PN, Church TM, Bowie AR, Marsay CM and others (2005) Iron in the Sargasso Sea (Bermuda Atlantic Timeseries Study region) during summer: Eolian imprint, spatiotemporal variability, and ecological implications. Global Biogeochem Cycles 19:GB4006, doi:10.1029/2004GB 002445

Smayda TJ (1969) Some measurements of the sinking rate of fecal pellets. Limnol Oceanogr 14:621-625

> Smith VH (2003) Eutrophication of freshwater and coastal marine ecosystems a global problem. Environ Sci Pollut Res 10:126-139

Steemann Nielsen E (1952) The use of radio-active carbon (14C) for measuring organic production in the sea. J Cons Int Explor Mer 18:117-140

Stoecker DK (1999) Mixotrophy among dinoflagellates. J Eukaryot Microbiol 46:397-401 
Strathmann RR (1967) Estimating the organic carbon content of phytoplankton from cell volume or plasma volume. Limnol Oceanogr 12:411-418

Strickland JDH, Parsons TR (1972) A practical handbook of seawater analysis. Bull Fish Res Board Can 167:1-310

Strom SL, Macri EL, Fredrickson KA (2010) Light limitation of summer primary production in the coastal Gulf of Alaska: physiological and environmental causes. Mar Ecol Prog Ser 402:45-57

Suggett DJ, Moore CM, Hickman AE, Geider RJ (2009) Interpretation of fast repetition rate (FRR) fluorescence: signatures of phytoplankton community structure versus physiological state. Mar Ecol Prog Ser 376:1-19

Tang EPY (1996) Why do dinoflagellates have lower growth rates? J Phycol 32:80-84

UNESCO (1981) International oceanographic tables, Vol 3. Joint Panel on Oceanographic Tables and Standards, UNESCO Technical Papers in Marine Science 39, Paris

Utermöhl H (1958) Zur Vervollkommnung der quantitativen Phytoplankton-Methodik. Mitt Int Ver Theor Angew Limnol 9:1-38

Editorial responsibility: William Kemp,

Cambridge, Maryland, USA
Valderrama JC (1981) The simultaneous analysis of total nitrogen and total phosphorus in natural waters. Mar Chem 10:109-122

Veldhuis MJW, Kraay GW (2004) Phytoplankton in the subtropical Atlantic Ocean: towards a better assessment of biomass and composition. Deep-Sea Res I 51:507-530

> Webb WL, Newton M, Starr D (1974) Carbon dioxide exchange of Alnus rubra. Oecologia 17:281-291

> Weston K, Fernand M, Mills DK, Delahunty R, Brown J (2005) Primary production in the deep chlorophyll maximum of the central North Sea. J Plankton Res 27:909-922

> Windolf J, Thodsen H, Troldborg L, Larsen SE, Bøgestrand J, Ovesen NB, Kronvang B (2011a) A distributed modeling system for simulation of monthly runoff and nitrogen sources, loads and sinks for ungauged catchments in Denmark. J Environ Monit 13:2645-2658

Windolf J, Wiberg-Larsen P, Bøgestrand J, Larsen SE and others (2011b) Vandløb 2010. NOVANA. Aarhus Universitet, DCE-Nationalt Center for Miljø og Energi, Videnskabelig rapport fra DCE, Nationalt Center for Miljø og Energi nr. 4. www.dmu.dk/pub/SR4.pdf

Submitted: January 29, 2014; Accepted: August 25, 2014 Proofs received from author(s): November 25, 2014 